\title{
Emerging roles of microRNAs as molecular switches in the integrated circuit of the cancer cell
}

\author{
GEORGIA SOTIROPOULOU, ${ }^{1}$ GEORGIOS PAMPALAKIS, ${ }^{1}$ EVI LIANIDOU, $^{2}$ and ZISSIMOS MOURELATOS $^{3}$ \\ ${ }^{1}$ Department of Pharmacy, School of Health Sciences, University of Patras, Rion-Patras 26500, Greece \\ ${ }^{2}$ Laboratory of Analytical Chemistry, Department of Chemistry, University of Athens, Athens 15771, Greece \\ ${ }^{3}$ Division of Neuropathology, Department of Pathology and Laboratory Medicine, University of Pennsylvania School of Medicine, Philadelphia, \\ Pennsylvania 19104, USA
}

\begin{abstract}
Transformation of normal cells into malignant tumors requires the acquisition of six hallmark traits, e.g., self-sufficiency in growth signals, insensitivity to antigrowth signals and self-renewal, evasion of apoptosis, limitless replication potential, angiogenesis, invasion, and metastasis, which are common to all cancers (Hanahan and Weinberg 2000). These new cellular traits evolve from defects in major regulatory microcircuits that are fundamental for normal homeostasis. The discovery of microRNAs (miRNAs) as a new class of small non-protein-coding RNAs that control gene expression post-transcriptionally by binding to various mRNA targets suggests that these tiny RNA molecules likely act as molecular switches in the extensive regulatory web that involves thousands of transcripts. Most importantly, accumulating evidence suggests that numerous microRNAs are aberrantly expressed in human cancers. In this review, we discuss the emergent roles of microRNAs as switches that function to turn on/off known cellular microcircuits. We outline recent compelling evidence that deregulated microRNAmediated control of cellular microcircuits cooperates with other well-established regulatory mechanisms to confer the hallmark traits of the cancer cell. Furthermore, these exciting insights into aberrant microRNA control in cancer-associated circuits may be exploited for cancer therapies that will target deregulated miRNA switches.
\end{abstract}

Keywords: miRNAs; oncomirs; tumor suppressor miRNAs; cancer-cell circuit; molecular switch

\section{INTRODUCTION}

MicroRNAs (miRNAs) were first described in Caenorhabditis elegans more than 15 years ago as part of a cascade that leads to post-transcriptional gene silencing (PTGS) (Lee et al. 1993). Today, miRNAs have been identified in mammals, including humans, as well as in fish, frogs, insects, worms, flowers, and viruses, where they act post-transcriptionally to reduce the levels of multiple target transcripts and their encoded proteins (for review, see Bartel 2004). A recent study estimates that the human genome contains an estimated number of 3441 miRNAs (Sheng et al. 2007), of which only 695 miRNAs were identified experimentally and were found scattered on all human chromosomes except for the $\mathrm{Y}$ chromosome (data were retrieved from miRBase: http://microrna.sanger.ac.uk/cgi-bin/sequences/mirna_summary.

Reprint requests to: Georgia Sotiropoulou, Department of Pharmacy, University of Patras, University Campus, Rion-Patras 26500, Greece; e-mail: gdsotiro@upatras.gr; fax: +30-2610-969940.

Article published online ahead of print. Article and publication date are at http://www.rnajournal.org/cgi/doi/10.1261/rna.1534709. pl?org=hsa). Based on this estimation, $\sim 2 \%-3 \%$ of human genes encode for miRNAs (Alvarez-Garcia and Miska 2005). MiRNAs regulate important cellular functions such as cell proliferation, apoptosis, differentiation, timing of developmental transitions, and organ development (AlvarezGarcia and Miska 2005). Accumulating evidence points to important roles exerted by specific miRNAs in cancer development and progression, as well as in other common diseases.

\section{Biosynthesis}

Most miRNAs are transcribed by RNA polymerase II as primary miRNAs (pri-miRNAs) that are $5^{\prime}$ 7-methylguanosine-capped and polyadenylated. The length of these transcripts varies from hundreds to thousands of nucleotides (Lee et al. 2004; Du and Zamore 2005; Liu et al. 2008). About $37 \%$ of human miRNAs are found in clusters that are transcribed as polycistronic RNAs (Altuvia et al. 2005). Subsequently, pri-miRNAs are processed by a $500-600-\mathrm{kDa}$ microprocessor complex that consists of the nuclear RNase III endonuclease Drosha and cofactor DiGeorge-syndrome 
critical region protein 8 (DGCR8) to generate pre-miRNAs that consist of 60-70 nucleotides (nt) with a $3^{\prime}$ overhang of 2 nt (Gregory et al. 2004). Pre-miRNAs are exported from the nucleus by exportin-5 (Yi et al. 2003; Lund et al. 2004). In the cytoplasm, the RNase III enzyme Dicer cleaves premiRNAs further to generate their mature forms, miRNAmiRNA*. Finally, one strand of the miRNA duplex is incorporated into the RNA-induced silencing complex (RISC) that mediates the gene suppression effect, while the other, miRNA*, is degraded (Gregory et al. 2005). Dicer was first recognized for its role in generating small interfering RNAs (siRNAs) that mediate RNA interference (RNAi) (Bernstein et al. 2001) and later was shown to play a role in miRNA maturation (Grishok et al. 2001; Hutvágner et al. 2001; Ketting et al. 2001). Further, Dicer, along with the transactivating response RNA-binding protein (TRBP), PACT, and an Argonaute protein, contribute to the formation of the RISC loading complex (Kim et al. 2009). In humans, four AGO proteins (AGO1-AGO4) have been described as being associated with miRNAs (Peters and Meister 2007). AGO2 represents the catalytic component of RISC for miRNA-mediated degradation of mRNA by displaying RNase $\mathrm{H}$ activity for RNA-RNA hybrids (Liu et al. 2004; Meister et al. 2004; Song et al. 2004). For this reason AGO2 is also referred to as slicer. AGO1, AGO3, and AGO4 lack endonuclease activity (Peters and Meister 2007). In addition, AGO2 was shown to interact with the elF4E factor that binds to $\mathrm{m}^{7} \mathrm{G}$ Cap sites and represses the translation of mRNAs (Kiriakidou et al. 2007). Argonautes may also function to inhibit protein production by actively translated ribosomes or ribosomes falling off during elongation (for review, see Hutvágner and Simard 2008). Finally, it has been demonstrated that RISC activity can be reconstituted after mixing small RNA with recombinant AGO2 (Rivas et al. 2005), and that fractionation of RISC activity followed by mass spectrometric analysis identifies AGO2 as the only protein present (Rand et al. 2004). Therefore, it can be concluded that AGO proteins along with miRNA form the effector RISC complex (Filipowicz et al. 2008).

A subset of miRNAs that are located inside introns is transcribed along with the corresponding genes (Ruby et al. 2007). These intronic miRNAs, also referred to as mirtrons, have been found in flies and worms (Okamura et al. 2007; Ruby et al. 2007). Recently, Berezikov et al. (2007) showed that mirtrons are also present in mammalian cells. Initial processing of mirtrons differs from that of miRNAs encoded by genes. Figure 1 illustrates known mechanisms of miRNA production in mammalian cells, including human. Irrespective of how miRNAs are produced, eventually they all display a hairpin-like structure that is further processed to yield mature miRNAs of 21-24 nt (Zamore and Haley 2005). Finally, a small percentage of miRNAs, found interspersed among repetitive elements, is transcribed by RNA polymerase III and, subsequently, processed in the same way (Borchert et al. 2006). Computational analyses showed that each miRNA recognizes hundreds of different transcript targets. Most miRNAs in animals function to inhibit effective mRNA translation through imperfect base pairing at their $3^{\prime}$ untranslated region (Bartel 2004). The underlying mechanism is currently not well understood, but it seems to involve the inhibition of translational initiation (Pillai et al. 2005). Using an in vitro translation system, it was shown recently that endogenous let-7 miRNAs could repress the $5^{\prime}$ cap recognition process while the transcript remains intact (Mathonnet et al. 2007).

\section{miRNA editing}

RNA editing is a process that results in the modification of adenosine to inosine, thus generating RNA and protein diversity in higher eukaryotes (for review, see Bass 2002). Inosine acts as guanosine during translation; therefore,

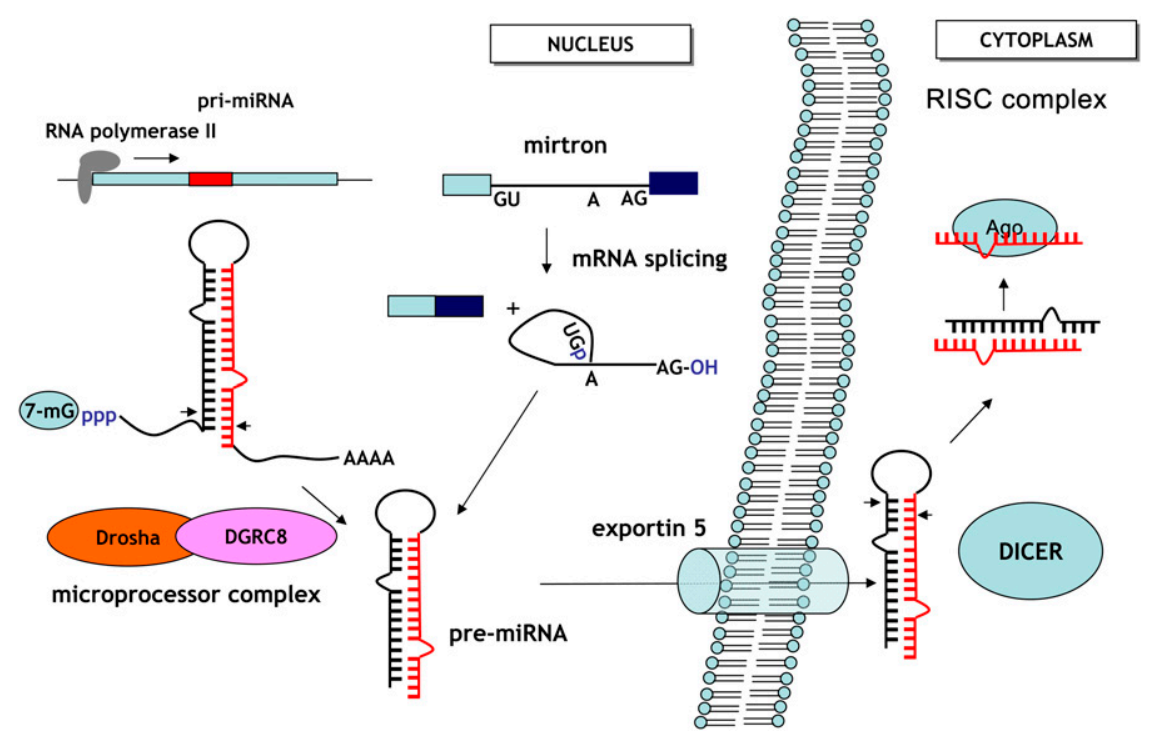

FIGURE 1. Mechanisms of microRNA production. Intracellularly, miRNAs can be generated either by transcription of a miRNA gene by RNA polymerase II (rarely by RNA polymerase III) or from introns containing miRNAs (mirtrons), as delineated in Drosophila (Ruby et al. 2007) and in humans (Berezikov et al. 2007). MiRNAs are derived from longer primary transcripts that contain one or more local hairpins, which are cleaved by RNase III to yield RNA duplexes of $\sim 21-24 \mathrm{nt}$ and single strands that associate with Argonaute proteins. Target selection in animals is dictated by sequences at the miRNA 5'end. Although most miRNAs end up in the cytoplasm, attachment of cis-acting regulatory motifs to certain miRNAs or siRNAs was shown to direct their nuclear import (Hwang et al. 2007). 
editing in coding regions results in amino acid changes in the encoded protein. Adenosine deaminases (ADARs) enzymes are responsible for this modification and were found ubiquitously expressed in mammals. ADARs recognize partially double-stranded RNA structures (Bass 2002). The stem-loop structure of miRNA precursors makes them targets for ADARs in vivo. miR-22 was the first miRNA shown to be edited in various tissues and to be present in low amounts in human and mouse brains, as well as in human lung and testis (Luciano et al. 2004). Recent studies showed that editing of miRNAs represents a control mechanism for biogenesis (Kawahara et al. 2007a) or altered specificity of miRNAs (Kawahara et al. 2007b) as shown for miR-376 (Kawahara et al. 2007b). For pre-miR-151, RNA editing affects its interaction with the Dicer-TRBP complex (Kawahara et al. 2007a). TRBP is an integral component of a Dicer-containing complex that is required for recruitment of Ago2 to miRNAs bound to Dicer (Chendrimada et al. 2005).

\section{MICRORNAS IN CANCER}

Recent studies implicate miRNAs in various diseases, including fragile X syndrome (Jin et al. 2004), DiGeorge syndrome (Gregory et al. 2004), Alzheimer's disease (Wang et al. 2008b), psoriasis (Sonkoly et al. 2007), diabetes (Tang et al. 2008), and obesity (Takanabe et al. 2008). This review will focus on the role of miRNAs in cancer. The first evidence for the involvement of miRNAs in cancer came from chronic lymphocytic leukemia (CLL), which represents the most common form of adult leukemia and is caused by a deletion in chromosomal locus 13q14 observed in $>50 \%$ of CLL patients. Interestingly, miR-15 and miR-16, which were mapped to this locus, were both shown to be deleted or down-regulated in CLL. Furthermore, in a subset of CLLs, a pre-miR-15 intermediate was detected by Northern blotting, indicating inefficient miR-15 processing (Calin et al. 2002). On the other hand, Dicer, which is responsible for miRNA production, is up-regulated in prostatic adenocarcinomas, leading to a global increase in miRNA levels (Chiosea et al. 2006). Dicer overexpression was also detected in lung adenocarcinomas (Chiosea et al. 2007), while reduced expression of Dicer is associated with a poor prognosis in lung cancer patients (Karube et al. 2005). Furthermore, Dicer gene amplifications are present in some cases of ovarian cancer (Zhang et al. 2006b), while alternative splicing of Dicer was observed in breast cancer (Irvin-Wilson and Chaudhuri 2005). Interestingly, an alternative promoter that modifies the length and the $5^{\prime}$ leader mRNA sequence is located $16 \mathrm{kbp}$ upstream of the initiation site and is active in primary breast cancer, but not in normal breast cells (IrvinWilson and Chaudhuri 2005). Similarly to CLL, deletion of the chromosomal region 11q23-24, where miR-125b resides, is often detected in breast, lung, and ovarian cancers (Negrini et al. 1995; Rasio et al. 1995). Furthermore, miR-
$125 \mathrm{~b}$ was found to be down-regulated in breast cancer (Iorio et al. 2005). MiR-140 was mapped on chromosome 6q22, again a genomic region often deleted in ovarian tumors, and miR-140 is down-regulated in ovarian cancers (Iorio et al. 2007). An extended survey of miRNA inactivation, which correlated with chromosomal deletions, was performed by Calin et al. (2004). On the other hand, global inhibition of miRNA processing was recently shown to lead to increased tumorigenicity and transformation, suggesting that the decreased expression of multiple miRNAs might be important in tumor formation and progression (Kumar et al. 2007).

The use of microarray technologies for analysis of miRNAs resulted in the rapid identification of miRNAs that are up- or down-regulated in various forms of cancer, including prostate (Porkka et al. 2007), breast (Iorio et al. 2005), ovarian (Iorio et al. 2007), colorectal (Cummins et al. 2006), kidney, and bladder cancer (Gottardo et al. 2007), as well as in cervical cancer cell lines (Lui et al. 2007). High-throughput methods for the rapid profiling of all known miRNAs were described (Nelson et al. 2004). Often, the term microRNome (in analogy to genome, transcriptome) is used to describe the set of miRNA species that are produced by a specific tissue (Cummins et al. 2006). Similarly to genes that encode for mRNAs, specific miRNAs were classified as oncogenes (oncomirs) or tumor suppressor genes based on their expression patterns in tumors and their cellular functions in the multistage process of malignant transformation and progression (Calin and Croce 2006; Esquela-Kerscher and Slack 2006; Zhang et al. 2007a). Table 1 illustrates miRNAs that are currently known to display deregulated expression in various forms of cancer based on microarray data subsequently verified by RT-PCR, qRT-PCR, or Northern blot analysis.

\section{The "expanded" integrated circuit of the cancer cell}

The model of the cellular integrated circuit proposed by Hanahan and Weinberg in their hallmark review (Hanahan and Weinberg 2000) suggests that cell signaling pathways mimic electronic integrated circuits, where transistors are replaced by proteins and electrons by phosphates and lipids. They suggested that progressive accumulation of genetic and epigenetic changes in the cancer cell genome results in deregulation of major regulatory microcircuits that proceeds in a combinatorial fashion to confer six hallmark phenotypic characteristics shared by most cancer cells, namely: sustained self-sufficiency to growth signals, insensitivity to antigrowth signals and self-renewal, evasion of apoptosis, limitless replicative potential, angiogenesis, invasion, and metastasis. It is reasonable to assume that each microcircuit is regulated by its own switch that will turn it on and off. Defects in these molecular switches result in wrong circuit activation/deactivation that results in aberrant signaling associated with transformation of a 
normal cell and malignant progression. With the identification and characterization of human miRNAs it becomes evident that this class of tiny molecules can play an important role as molecular switches, in analogy to the electrical switch, that will turn the expression of specific proteins on and off. Recent studies indicate that specific miRNAs regulate the expression of major metastasisassociated genes. Interestingly, "miRNA switches" can direct an epithelial-tomesenchymal transition (EMT), a critical change of the cell phenotype that promotes cancer metastasis. In Figure 2, we have attempted to update the schematic representation of the integrated cancer-cell circuit, originally described by Hanahan and Weinberg (2000), in view of the massive information published in recent years on the important roles played by "miRNAs switches" in the deregulation of cellular signaling and the acquisition of the above six hallmark traits of the cancer cell, as described below.

\section{Self-sufficiency in growth signals}

Normal cells require mitogenic signals in order to leave the quiescent state and become actively proliferating cells. Many cancer cells can produce their own growth factors in order to succeed at this, a condition known as autocrine regulation (Fedi et al. 1997). RAS is a major intermediate regulator that participates in the aforementioned signaling cascade. RAS is mutated in many malignancies; however, miRNAs provide an alternative way to control the expression of RAS protein levels. It has been well established that let-7 binds to the 3' UTR of RAS mRNA, thus inhibiting translation (Johnson et al. 2005). H-RAS, N-RAS, and $K$-RAS all have let-7 binding sites at their $3^{\prime}$ UTRs. Due to frequent down-regulation of let-7 in tumors, it is suggested that this miRNA has tumor suppressor activity. In concordance with this, it was found that
TABLE 1. miRNAs with altered expression in cancer determined by Northern blotting, quantitative RT-PCR, or semiquantitative RT-PCR

\begin{tabular}{|c|c|c|c|c|}
\hline miRNA & Cancer type & Method & Up or down & Reference \\
\hline let-7a & Gastric & Q & $\downarrow$ & Zhang et al. (2007b) \\
\hline miR-9 & Breast & Q & $\uparrow$ & Ma et al. (2007) \\
\hline miR-10b & Breast (metastatic) & $\mathrm{Q}$ & $\uparrow$ & Ma et al. (2007) \\
\hline miR-10b & Glioblastoma & $\mathrm{N}$ & $\uparrow$ & Ciafrè et al. (2005) \\
\hline miR-15 & CLL & $\mathrm{N}$ & $\downarrow$ & Calin et al. (2002) \\
\hline miR-15a & Pituitary adenomas & $\mathrm{N}$ & $\downarrow$ & Bottoni et al. 2005 \\
\hline miR-16 & CLL & $\mathrm{N}$ & $\downarrow$ & Calin et al. (2002) \\
\hline miR-16-1 & Pituitary adenomas & $\mathrm{N}$ & $\downarrow$ & Bottoni et al. (2005) \\
\hline miR-17-5p & Breast cancer cell lines & $\mathrm{N}$ & $\downarrow$ & Hossain et al. (2006) \\
\hline miR-17-92 & Lymphoma & Q & $\uparrow$ & He et al. (2005b) \\
\hline miR-17-92 & Colorectal & $\mathrm{Q}$ & $\uparrow$ & He et al. (2005b) \\
\hline miR-21 & $\mathrm{HCC}$ & $\mathrm{N}$ & $\uparrow$ & Meng et al. (2007) \\
\hline miR-21 & Breast & $\mathrm{N}$ & $\uparrow$ & Iorio et al. (2005) \\
\hline $\mathrm{miR}-21$ & $\begin{array}{l}\text { Well-differentiated pancreatic } \\
\text { endocrine carcinoma } \\
\text { following liver metastasis }\end{array}$ & $\mathrm{N}$ & $\uparrow$ & Roldo et al. (2006) \\
\hline miR-21 & Cervical cancer cell lines & $\mathrm{N}$ & $\uparrow$ & Lui et al. (2007) \\
\hline miR-21 & Cholangiocarcinoma cell lines & $\mathrm{N}, \mathrm{Q}$ & $\uparrow$ & Meng et al. (2006) \\
\hline miR-29a & CLL & Q & $\uparrow$ & Zanette et al. (2007) \\
\hline miR-29c & CLL & $\mathrm{Q}$ & $\uparrow$ & Zanette et al. (2007) \\
\hline miR-34a & CLL & $\mathrm{Q}$ & $\uparrow$ & Zanette et al. (2007) \\
\hline miR-34a & Neuroblastoma & $\mathrm{Q}$ & $\downarrow$ & Welch et al. (2007) \\
\hline miR-34a & Colon & $\mathrm{Q}$ & $\downarrow$ & Tazawa et al. (2007) \\
\hline miR-103 & $\begin{array}{l}\text { Well-differentiated pancreatic } \\
\text { endocrine carcinoma }\end{array}$ & $\mathrm{N}$ & $\uparrow$ & Roldo et al. (2006) \\
\hline miR-122 & $\mathrm{HCC}$ & $\mathrm{N}$ & $\downarrow$ & Kutay et al. (2006) \\
\hline miR-125b & Breast & $\mathrm{N}$ & $\downarrow$ & lorio et al. (2005) \\
\hline miR-125b1 & Ovary & $\mathrm{N}$ & $\downarrow$ & lorio et al. (2007) \\
\hline miR-127 & Cervical SSC & $\mathrm{Q}$ & $\uparrow$ & Lee et al. (2008) \\
\hline miR-128 & Glioblastoma & $\mathrm{N}$ & $\downarrow$ & Ciafrè et al. (2005) \\
\hline miR-128b & ALL & Q & $\uparrow$ & Zanette et al. (2007) \\
\hline miR-140 & Ovary & $\mathrm{Q}$ & $\downarrow$ & lorio et al. (2007) \\
\hline miR-141 & Ovary & $\mathrm{N}$ & $\uparrow$ & lorio et al. (2007) \\
\hline miR-141 & Cholangiocarcinoma cell lines & $\mathrm{N}, \mathrm{Q}$ & $\uparrow$ & Roldo et al. (2006) \\
\hline miR-143 & CLL & $\mathrm{R}, \mathrm{Q}$ & $\downarrow$ & Akao et al. (2007) \\
\hline miR-143 & Colorectal neoplasia & $\mathrm{N}$ & $\downarrow$ & Michael et al. (2003) \\
\hline miR-143 & B-cell lymphoma & $\mathrm{R}, \mathrm{Q}$ & $\downarrow$ & Akao et al. (2007) \\
\hline miR-143 & Cervical cancer cell lines & $\mathrm{N}$ & $\downarrow$ & Lui et al. (2007) \\
\hline miR-145 & Breast & $\mathrm{N}$ & $\downarrow$ & lorio et al. (2005) \\
\hline miR-145 & Colorectal neoplasia & $\mathrm{N}$ & $\downarrow$ & Michael et al. (2003) \\
\hline miR-145 & Ovary & $\mathrm{N}$ & $\downarrow$ & lorio et al. (2007) \\
\hline miR-145 & CLL & $\mathrm{R}, \mathrm{Q}$ & $\downarrow$ & Akao et al. (2007) \\
\hline miR-145 & B-cell lymphoma & $\mathrm{R}, \mathrm{Q}$ & $\downarrow$ & Akao et al. (2007) \\
\hline miR-146b & PTC & $N, R$ & $\uparrow$ & He et al. (2005a) \\
\hline miR-155 & Breast & $\mathrm{Q}$ & $\uparrow$ & Ma et al. (2007) \\
\hline miR-155 & Pancreas & $\mathrm{N}$ & $\downarrow$ & Roldo et al. (2006) \\
\hline miR-155 & Lymphomas & $\mathrm{Q}$ & $\uparrow$ & Eis et al. (2005) \\
\hline miR-181a & Glioblastoma & $\mathrm{N}$ & $\downarrow$ & Ciafrè et al. (2005) \\
\hline miR-181b & Glioblastoma & $\mathrm{N}$ & $\downarrow$ & Ciafrè et al. (2005) \\
\hline miR-181b & PTC & $\mathrm{N}, \mathrm{Q}$ & $\uparrow$ & Pallante et al. (2006) \\
\hline miR-181b-1 & ALL & $\mathrm{Q}$ & $\uparrow$ & Zanette et al. (2007) \\
\hline miR-184 & Tongue SSC & Q & $\uparrow$ & Wong et al. (2008) \\
\hline miR-195 & CLL & $\mathrm{Q}$ & $\uparrow$ & Zanette et al. (2007) \\
\hline miR-199a & Ovary & $\mathrm{N}$ & $\downarrow$ & lorio et al. (2007) \\
\hline miR-199a & Cervical SSC & Q & $\uparrow$ & Lee et al. (2007b) \\
\hline miR-200a & Ovary & $\mathrm{N}$ & $\uparrow$ & lorio et al. (2007) \\
\hline miR-204 & ALL & $\mathrm{Q}$ & $\uparrow$ & Zanette et al. (2007) \\
\hline miR-204 & Pancreas (insulinomas) & $\mathrm{N}$ & $\uparrow$ & Roldo et al. (2006) \\
\hline
\end{tabular}

(continued) 
TABLE 1. Continued

\begin{tabular}{|c|c|c|c|c|}
\hline miRNA & Cancer type & Method & Up or down & Reference \\
\hline miR-218 & ALL & Q & $\uparrow$ & Zanette et al. (2007) \\
\hline miR-221 & PTC & $\mathrm{N}, \mathrm{Q}$ & $\uparrow$ & Eis et al. (2005) \\
\hline miR-221 & PTC & $N, R$ & $\uparrow$ & He et al. (2005a) \\
\hline miR-221 & Glioblastoma & $\mathrm{N}$ & $\uparrow$ & Ciafrè et al. (2005) \\
\hline miR-222 & PTC & $\mathrm{N}, \mathrm{Q}$ & $\uparrow$ & Eis et al. (2005) \\
\hline miR-222 & PTC & $\mathrm{R}$ & $\uparrow$ & He et al. (2005a) \\
\hline miR-331 & ALL & Q & $\uparrow$ & Zanette et al. (2007) \\
\hline miR-331 & CLL & Q & $\uparrow$ & Zanette et al. (2007) \\
\hline miR-372 & Testicular & $\mathrm{N}$ & $\uparrow$ & Voorhoeve et al. (2006) \\
\hline miR-373 & Breast cancer metastasis & Q & $\uparrow$ & Huang et al. (2008) \\
\hline
\end{tabular}

(CLL) Chronic lymphocytic leukemia; (PTC) pappilary thyroid carcinoma; (HCC) hepatocellular carcinoma; (ALL) acute lymphoblastic leukemia; (SSC) squamous cell carcinoma; (N) Northern blotting; (Q) quantitative RT-PCR; (R) semiquantitative RT-PCR. let-7 targets the HMGA-2 oncogene (Lee and Dutta 2007), down-regulates $M Y C$, and can revert MYC-induced growth of Burkitt lymphoma cells (Sampson et al. 2007). It should be noted, however, that one member of the let-7 family, let$7 \mathrm{a}-3$, is heavily methylated in normal lung cells, while it is hypomethylated and expressed in a subset of lung adenocarcinomas. Therefore, it was concluded that this member may have a tumor-promoting role (Brueckner et al. 2007). Recently, let-7 was used as a model to investigate the mechanism of miRNA-induced inhibition of mRNA translation initiation (Kiriakidou et al. 2007). The miRNA let-7 is also considered a marker for less advanced cancer, and more importantly, a better marker than E-cadherin (Shell et al. 2007). Most importantly, let-7 targets Dicer, which has three highly conserved let-7 sites, pointing to a negative feedback mechanism on miRNA processing (Forman et al. 2008).

Up-regulation of cell surface receptors results in hypersensitivity of cancer cells to low concentrations of growth factors that normally do not trigger proliferation. Deregulation of miRNA expression in cancer can result in aberrant regulation of cell surface receptors. miRNA-125a and miRNA-125b target the oncogenes ERBB2 and ERBB3 that encode for cellular receptors (Scott et al. 2007). Estrogen Receptor alpha $(\mathrm{ER} \alpha)$ represents a key regulator in cancer cell signaling. Alterations in the expression of genes that are under hormonal regulation are a very common event in cancer, especially in hormonally regulated tumors, such as breast, ovarian, and prostate. As is shown in Figure 2, miR206 down-regulates protein and mRNA levels of ER $\alpha$ (Adams et al. 2007). Reduction of ER $\alpha$ levels in the cells is expected to have a great impact in the expression profiles of estrogen-responsive genes. For example, kallikreinrelated peptidases, the largest group of serine proteases in the human genome that includes 15 members, are well documented to be regulated by hormonal receptors (Borgoño and Diamandis 2004). Furthermore, many members of this family are characterized by their concurrent down- or up-regulation in various forms of cancer. Some members of this family have extracellular matrix-degrading activity, while one member (KLK10) is a tumor suppressor in breast cancer. It is possible that differential expression of miRNAs that target $\mathrm{ER} \alpha$ could be responsible for switching on/off the expression of KLK genes. $\mathrm{ER} \alpha$ is also targeted by $\mathrm{miR}-221$ and miR-222, two miRNAs found to be specifically elevated in ER $\alpha$-negative breast cancer cell lines. Most importantly, it was demonstrated that knockdown of miR-221 and/or miR-222 expression sensitizes breast cancer cells to tamoxifen (Zhao et al. 2008), while ectopic expression confers resistance, as expected (Miller et al. 2008).

Insensitivity to antigrowth signals and increased capacity of self-renewal

As described by Hanahan and Weinberg (2000), antigrowth signals act in two different ways, either to force cells to enter a quiescent phase or to differentiate. TGF- $\beta$ is a major regulator of cell signaling that transduces antigrowth signals via multiple pathways, but mainly through prevention of phosphorylation and inactivation of the tumor suppressor protein $\mathrm{Rb}$, an effect mediated by p15 (Hannon and Beach 1994). Recently, miR-106 was shown to target retinoblastoma 1 and miR-20a, the receptor of TGF- $\beta$ (Volinia et al. 2006). MiR-124a is epigenetically silenced in human cancer cells, and its down-regulation was correlated with $\mathrm{Rb}$ hypophosphorylation (Lujambio et al. 2007). As mentioned, miRNAs are important regulators of cell differentiation, as shown for members of the let-7 family in tissue regeneration studies in newts: During initiation of regeneration in newt lens and inner ear hair cells, which is characterized by dedifferentiation of terminally differentiated cells, all let-7 members were found to be downregulated (Tsonis et al. 2007).

On the other hand, miR-17-92 was implicated in erythroleukemia. This polycistron is derived from a miRNA cluster that resides in intron 3 of the C13orf 25 gene on human chromosome 13q31.3 and contains seven miRNAs: miR-17-5p, miR-17-3p, miR-18, miR-19a, miR-20, miR19b-1, and miR-92-1. In a mouse model infected with the Friend murine leukemia virus that causes retroviral insertional mutagenesis, induction of erythroleukemia was observed upon insertion of the viral genome 298 base pairs (bp) upstream of the miR-17-92 polycistron. This insertion results in activation of the gene cluster, enhancement of erythroblast transformation, and proliferation. Under these conditions, erythroleukemic cells became erythropoietin-dependent and altered their normal response to 


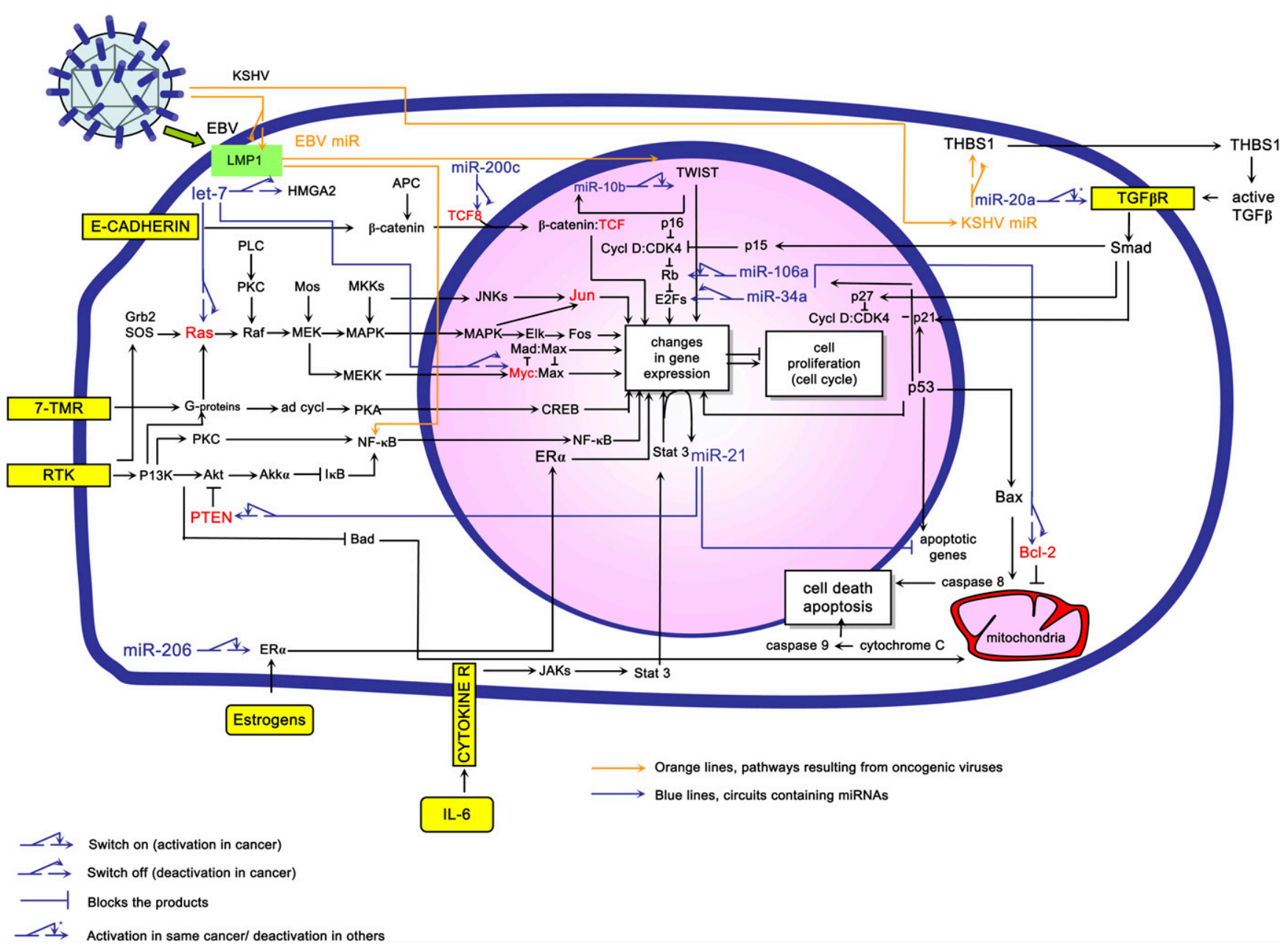

FIGURE 2. The "expanded" integrated circuit of the cancer cell. Cell signaling pathways resemble an electronic integrated circuit, where miRNAs act as switches that turn the circuits on/off. Up- or down-regulation of specific miRNAs in cancer results in turning on/off specific cellular microcircuits. In addition, these switches may be controlled by miRNAs encoded by oncogenic viruses. It should be noted that genetic reprogramming of the integrated cell circuit during malignant transformation and/or progression (e.g., mutation of p53) most likely cooperates with miRNA-mediated signaling (based on data from Fig. 2 of Hanahan and Weinberg [2000]).

erythropoietin from maturation to self-renewal (Cui et al. 2007). The same activation event was observed previously in mice infected with the SL3-3 murine leukemia virus (Wang et al. 2006). Further, two mouse models that expressed miR-17-92 were generated following its identification as an oncogene (oncomir) (He et al. 2005b; Lu et al. 2007). In the first case, expression of the miR-17-92 cluster or a truncated form of the cluster (miR-17-19b-1) in cooperation with c-myc expression resulted in significant acceleration of tumor development in a mouse model for B-cell lymphoma (He et al. 2005b). In the other case, in order to study potential developmental effects, a transgenic mouse was produced that overexpresses the mouse miR-17-92 cluster in lungs under the control of the mouse surfactant protein C promoter ( $\mathrm{Lu}$ et al. 2007). MiR-17-92 overexpression caused major abnormalities in the lungs, while some of the animals were born dead without air in their lungs ( $\mathrm{Lu}$ et al. 2007).
An increasing number of recent studies confirm the existence of cancer stem cells (or tumor-initiating cells), which are rare cells with indefinite proliferative potential that are believed to trigger tumor formation (Reya et al. 2001). Due to the fact that both cancer cells and normal stem cells share similar potential to indefinitely self-renew, it is logical to assume that cancer stem cells use the same machinery for self-renewing cell division as that used by normal stem cells. MiRNAs play important roles in determining the self-renewal potential of normal stem cells during development (Zhang et al. 2006a). Let-7 was found to be down-regulated in breast cancer stem cells, but its expression was induced upon induction of differentiation in breast cancer stem cells (or breast-tumor-initiating cells) (Yu et al. 2007). Lentiviral transduction of let-7a into breast-tumor-initiating cells resulted in reduction of tumor formation in SCID mice, and reduced the burden of liver and lung metastasis, as well as their self-renewal ability (Yu 
et al. 2007). The inhibition of self-renewal is partly attributed to inhibition of RAS by let-7, while the induction of differentiation is partly due to inhibition of HMGA2. Also, let-7 expression was shown to deplete self-renewal of mammary progenitor cells (Ibarra et al. 2007).

\section{Evading apoptosis: The role of oncomirs}

Oncogenic miRNAs, also known as oncomirs, usually promote tumor development by inhibiting known tumor suppressor genes or genes that control cell differentiation or apoptosis (Cho 2007; Zhang et al. 2007a). As shown by several studies, expression of the miR-21 oncomir is regulated by an upstream enhancer located $\sim 800$ bp upstream of the transcriptional start site that contains two functional stat 3 binding sites (Löffler et al. 2007). In myeloma cells, activation of stat3 by IL- 6 activates miR-21, providing the basis for IL-6dependent survival of multiple myeloma cells. Withdrawal of IL-6 results in rapid apoptosis of INA myeloma cells. However, ectopically expressed miR-21 inhibited significantly the number of cells undergoing apoptosis (Löffler et al. 2007). The tumor suppressor gene tropomyosin 1 (TPM1) is another target of the miR-21 oncomir that specifically inhibits translation of TPM1 mRNA, while TPM1 mRNA levels remain constant (Zhu et al. 2007). Furthermore, miR-21 targets the tumor suppressor genes PTEN (phosphatase and tensin homolog deleted on chromosome 10) (Meng et al. 2007), PDCD4 (programmed cell death 4) (Asangani et al. 2008; Frankel et al. 2008; Zhu et al. 2008), and maspin (Zhu et al. 2008). Additionally, miR-21 is induced by AP-1 in response to RAS activation. Because PDCD4 is a negative regulator of AP-1, down-regulation of PDCD4 by miR-21 provides an autoregulatory loop that controls RAS-mediated AP-1 activity (Talotta et al. 2009). Moreover, it was shown that inhibition of miR-21 in MCF-7 resulted in the up-regulation of various genes (FAM3C, ACTA2, APAF1, BTG2, FAS, $C D K N 1 A$, and SESN1) that are known to be controlled by p53. However, miR-21 does not target p53 directly; therefore, miR-21 likely antagonizes the p53 pathway via other downstream targets (Frankel et al. 2008). Interestingly, inhibition of miR-21 in MDA-MB-231 has a subtle effect on the growth of primary tumors, but it significantly reduces invasion and lung metastasis (Zhu et al. 2008).

Mutations in p53 are found nearly in all types of cancer. Importantly, p53 regulates the expression of the miR-34 family of miRNAs, which consists of three members: miR$34 \mathrm{a}$, which is generated from a transcriptional unit located on chromosome 1p36, and miR-34b and miR-34c, both of which are produced by processing of a bicistronic transcript from chromosome 11q23 (Bommer et al. 2007). The miR-34 family is down-regulated in cancer cells either due to p53 inactivation by mutations or epigenetically (Hermeking 2007). In neuroblastoma, loss of miR-34a was observed, which is probably caused by a $1 \mathrm{p} 36$ deletion (Welch et al. 2007). It is likely that miR-34 family members are necessary mediators of the p53 tumor suppressor activity, since the ectopic expression of miR-34a causes a cell-cycle arrest in G1 phase (Bommer et al. 2007; He et al. 2007; Tarasov et al. 2007), as did miR-34b/c (He et al. 2007). In addition, upon ectopic expression of miR-34a, human colon cancer cell lines HCT116 and RKO showed signs of senescence (Tazawa et al. 2007). Moreover, miR-34a suppressed the formation of tumors by HCT116 and RKO cells in mice. Gene-expression microarray and immunoblot analyses revealed down-regulation of the E2F pathway by miR-34a and up-regulation of the p53 pathway (Tazawa et al. 2007). In another study, it was shown that miR-34b and miR-34c cooperate in suppressing proliferation and soft-agar colony formation of neoplastic epithelial ovarian cells, while doxorubicin, which up-regulates p53, also up-regulates the expression of these two miRNAs (Corney et al. 2007). Furthermore, direct binding of p53 to a promoter element on the miR-34a promoter was demonstrated (Raver-Shapira et al. 2007; Tarasov et al. 2007). In addition, inactivation of miR-34a compromises p53-dependent apoptosis, indicating that miR-34a is a proapoptotic transcriptional target of p53 (Raver-Shapira et al. 2007). Indeed, other groups have verified that expression of miR34a can induce apoptosis (Chang et al. 2007; Welch et al. 2007). Transfection of an episomal plasmid driving the conditional expression of miR-34a in U2OS osteosarcoma cells and conditional up-regulation of its expression resulted in a significant decrease of colony formation (Tarasov et al. 2007). Finally, miR-34a-deficient embryonic stem cells showed a slight decrease in spontaneous apoptosis after differentiation, while BCL2 was identified as one of miR34a targets (Bommer et al. 2007). Based on these observations, the miR-34 gene family was suggested as a new tumor suppressor miRNA family. On the other hand, miR-125b was implicated in the development of androgen-independent prostate cancer (Shi et al. 2007). Differential expression of miR-125b in androgen-dependent and -independent prostate cancer cells, as well as in benign and malignant prostate tissues, has been observed. Androgen-induced expression of miR-125b-2 is mediated by androgen receptor binding on the miR-125b-2 promoter (Shi et al. 2007). MiR-125b suppresses the expression of the proapoptotic gene Bakl and induces androgen-independent growth of prostate cancer cells; therefore, it was suggested that miR-125b functions as an oncomir in prostate cancer. Recently, it was shown that miRNAs can modulate TRAIL-induced apoptosis by indirectly targeting caspases (Ovcharenko et al. 2007). MiR-133 is the only miRNA that was shown to down-regulate the levels of caspase- 9 by direct interaction (Xu et al. 2007). Finally, miR-15 and miR-16 induce apoptosis by targeting the antiapoptotic gene BCL2 (Cimmino et al. 2005).

\section{Limitless replicative potential}

Limitless replicative potential is correlated with progressive shortening of telomere sequences located at the end of 
chromosomes containing the motif (TTAGGG) $)_{n}$. In every cell division, telomeres lose $50-150$ bp to a certain threshold, at which an irreversible growth arrest is triggered, which is referred to as senescence. Cancer cells have adapted mechanisms to escape this limitation, acquiring a limitless replicative potential phenotype. Telomere length is maintained by the enzyme telomerase, human telomere reverse transcriptase (hTERT), which is a reverse transcriptase that synthesizes the telomeres at the ends of the chromosomes (Blackburn 2001). Another mechanism that maintains the length of telomeres is the alternative lengthening of telomeres (ALT) (Muntoni and Redder 2005), which relies on homologous recombination events at telomeres. Many miRNAs were predicted to target the mRNA that encodes for hTERT. However, only miR-138 was functionally related to the regulation of $h T E R T$ (Mitomo et al. 2008). miR-138 expression was found to be down-regulated in anaplastic thyroid carcinoma cell lines, leading to overexpression of $h T E R T$. Interestingly, miRNAs may regulate $h T E R T$ expression in a subset of osteosarcomas, since in some osteosarcoma cell lines expression of the $h T E R T$ mRNA did not correlate with protein levels (Blackburn 2001).

Dicer1 deficiency results in decreased DNA methylation in mouse embryonic stem cells. Specifically, Dicer1-null cells displayed reduced amounts of DNMT1, DNMT3a, and DNMT3b and were characterized by hypomethylation of genomic DNA, including subtelomeric regions of chromosomes. On the other hand, retinoblastoma-like protein 2 (Rbl-2) and retinoblastoma proteins, in general, are repressors of DNMT3a and DNMT3b. The Rbl-2 transcript is a direct target of the miR-290 family (Benetti et al. 2008; Sinkkonen et al. 2008). In fact, all members of the miR-290 family except for miR-290 (i.e., miR-291-3p, miR-291-5p, miR-292-3p, miR-292-5p, miR-293, miR-294, miR-295) were shown to repress $R b l-2$ mRNA and protein levels. These results show that defects in DNA methylation lead to increased telomere recombination and aberrant telomere elongation, as demonstrated in the Dicer1-null embryonic stem cells (Benetti et al. 2008).

\section{Angiogenesis}

Angiogenesis plays an important role in cancer growth and progression, since it provides tumor cells with nutrients. Vascular endothelial cells are stimulated by proangiogenic factors secreted by tumor cells to undergo distinctive phenotypic changes that finally give rise to new mature blood vessels. The first evidence for the involvement of miRNAs in the regulation of angiogenesis came from Dicer knockout mice carrying a deletion by homologous recombination of the first two exons. Knockout mice died between 12.5 and $14.5 \mathrm{~d}$ of gestation, and it was found that their blood vessel formation was compromised (Yang et al. 2005). Recently, miR-221 and miR-222 were shown to modulate the stem cell factor (SCF) by targeting its receptor c-kit. Activation of c-kit by SCF controls tube formation, migration, and survival of HUVEC (Poliseno et al. 2006). Retroviral transduction of miR-17-92 into p53-null mouse colonocytes resulted in down-regulation of thrombospondin 1 (THBS1) and connective tissue growth factor (CTGF) and concomitant inhibition of angiogenesis (Dews et al. 2006). Knockdown of miR-17-92 resulted in partial restoration of THBS1 and CTGF protein expression (Dews et al. 2006). Under hypoxic conditions in CNE human nasopharyngeal cancer cells, VEGF is up-regulated due to down-regulation of specific miRNAs that blocked its expression. Using miRNA chip assays, it was shown that VEGF mRNA is targeted by miR-15b, miR-16, miR-20a, and miR-20b (Hua et al. 2006). Transfection of cells with the above miRNAs resulted in reduction of VEGF protein levels. Furthermore, miRNAs can regulate other angiogenic factors, such as cycloxygenase 2 (COX2), uPAR, and c-MET. More specifically, miR-20b, miR-15b, and miR-16 target COX2; miR$15 \mathrm{~b}$ and miR-16 were shown to down-regulate uPAR; while c-MET is down-regulated by miR-15b, miR-16, miR-20a, and miR20b (Hua et al. 2006).

The major antiangiogenic homeobox gene $G A X$ as well as HOXA5 are direct targets of miR-130a (Chen and Gorski 2008). Quiescent endothelial cells express $G A X$ but they do not express miR-130a. Induction of proliferation and differentiation by serum, proangiogenic factors (VEGF or bFGF), or proinflammatory factors (TNF-a) results in the expression of miR-130a and down-regulation of $G A X$ and HOXA5. HOXA5 is an interesting molecule because it inhibits the expression of VEGF receptor 2 (VEGFR2), COX-2, and other important angiogenesis-associated genes. This fact probably indicates that resting cells express low levels of critical angiogenesis genes; however, induction of proliferation down-regulates the expression of HOXA5 mediated by miR-130a, while it further enhances the angiogenesis potential by inducing the cell to express its own angiogenesis genes. In addition, miR-126 is another miRNA that regulates the response of endothelial cells to VEGF (Fish et al. 2008) and FGF (Wang et al. 2008a), and developmental angiogenesis in vivo (Wang et al. 2008a). It is located inside an intron sequence of the Egfl7 gene and is regulated by a negative feedback loop (Fish et al. 2008). The function of miR-126 has been elucidated with the use of animal models. Specifically, it was shown that knockdown of miR-126 in zebrafish resulted in loss of vascular integrity and hemorrhage during embryonic development. However, miR-126 is not sufficient by itself to promote differentiation of pluripotent cells toward the endothelial lineage (Fish et al. 2008). A targeted deletion of miR-126 (miR$126^{-/-}$) in mice results in similar effects, including leaky vessels, hemorrhaging, and partial $(\sim 40 \%)$ embryonic lethality. MiR-126 $6^{-1-}$ mice that survived to adulthood appeared normal, indicating the important effect of miR-126 in vascular integrity during embryogenesis (Wang et al. 
2008a). MiR-126-targeted deletion reduces survival after myocardial infraction, since neovascularization is essential for cardiac repair (Wang et al. 2008a). Other miRNAs that were implicated in promoting angiogenesis include miR378 (Lee et al. 2007a), miR-27b, and let-7f (Kuehbacher et al. 2007), while miRNAs may also act via interconnected complex networks. It was described that RAS modulates $m y c$ activity to repress the thrombospondin-1 (Watnick et al. 2003). This results in a new microcircuit within cells. Viral miRNAs also target antiangiogenic factors, as was demonstrated for KSHV-encoded miRNAs that target THBS1 (Samols et al. 2007).

Invasion and metastasis: Epithelial-to-mesenchymal transition

Transition to the invasive/metastatic phenotype is necessary for primary tumor cells, in order for them to escape from the primary site and colonize a new tissue in the body. Recently, it was shown that miR-10b acts to promote metastasis of breast cancer (Ma et al. 2007). This study indicated that miRNAs likely play an important role in regulating the invasive and metastatic potential of the cancer cell. It was demonstrated that miR-10b expression levels in MDA-MB-231 (a metastatic breast cancer cell line) were increased by 50 -fold when compared with MCF-7 (a nonmetastatic breast cancer cell line). Silencing of miR-10b resulted in a 10-fold reduction of the invasive properties of MDA-MB-231 cells assessed in vitro. Ectopic expression of miR-10b in the nonmetastatic breast cancer cell line SUM149 had no effect on the in vivo growth rate of cells implanted in SCID mice, but it increased dramatically the in vivo invasive potential of these cells. Furthermore, induction of miR-10b expression initiated the formation of lung metastasis. These results were confirmed by using another nonmetastatic breast cancer cell line, SUM159, in which ectopic expression of $\mathrm{miR}-10 \mathrm{~b}$ resulted in the appearance of metastatic sites in the lungs and peritoneum (Ma et al. 2007). Detailed molecular analysis identified the transcription factor Twist as a key molecule for miR-10b up-regulation. Twist acts as a master regulator not only in morphogenesis but also in metastasis. Twist is responsible for the induction of epithelial-to-mesenchymal transition (EMT) (Yang et al. 2004). Furthermore, Twist is up-regulated by the LMP1 protein of Epstein-Barr virus (EBV) (Horikawa et al. 2007), a protein that is autoregulated by BARTs miRNAs encoded by EBV (Lo et al. 2007). Recently, it was shown that TGF- $\beta$ signaling induces HMGA2, which, in turn, mediates EMT. Twist is also up-regulated by TGF- $\beta$ and synergistically up-regulated with HMGA2 and TGF- $\beta$ (Thuault et al. 2006). Finally, up-regulation of Twist induces tumor angiogenesis (Niu et al. 2007), thus linking the invasive potential of the cancer cell to neovascularization.

Generally, EMTs are required for the acquisition of metastatic potential by transformed cells. Recently, several miRNAs were identified that regulate the transition from the epithelial-to-mesenchymal phenotype, thereby increasing the aggressiveness of cancer cells. The miR-200 family (miR-200a, miR-200b, miR-200c, and miR-429) has recently attracted attention as a regulator of EMT. All members of the miR-200 family are down-regulated upon induction of EMT transition of mouse mammary epithelial cells induced by TGF- $\beta$ (Korpal et al. 2008). Re-expression of the miR-200 family was able to reverse the mesenchymal phenotype of $4 \mathrm{TO} 7$ metastatic breast cancer cells (Korpal et al. 2008). Stable overexpression of miR-200c in A549 nonsmall cell lung carcinoma resulted in a loss of ZEB1 (also referred to as TCF8, $\delta E F 1$, Nil-2- $\alpha$ ) and an increase of E-cadherin expression. Also, miR-200c when expressed in MDA-MB-231 restored E-cadherin expression, which represents a major event in EMT (Thiery 2002). Furthermore, miR-200b mediates the posttransciptional repression of ZEB2 (Christoffersen et al. 2007), which is involved in regulation of the TGF- $\beta$ pathway and induction of EMT, while it induces $\mathrm{Rb}$ hypophosphorylation (Mejlvang et al. 2007).

Recently, it was demonstrated that miR-373 and miR520c promote breast cancer metastasis. MCF-7, a nonmigratory, nonmetastatic breast cancer cell line, was transfected with a library of human miRNAs. Transfectants were subjected to multiple rounds of trans-well cell migration assay, and miR-373, miR-520c, and miR-520e were found to stimulate cell migration. Enforced expression of miR373 or miR-520c produced a potent migratory phenotype in MCF-7 cells. In addition, injection of MCF-7 transfected with miR-373 or miR-520c in the tail vein of SCID mice resulted in extensive lung and osteolytic metastasis. This effect was attributed, at least in part, to down-regulation of CD44, a cell surface receptor of hyaluronan. Knockdown of CD44 in MCF-7 cells by shRNA had similar in vivo effects as observed when miR-373 or miR-520c became up-regulated (Huang et al. 2008). It should be noted that miR-373 was recently shown to up-regulate the expression of E-cadherin in PC-3 prostate cancer cells by targeting complementary promoter regions in the encoding gene, a phenomenon named RNA activation (RNAa). RNAa represents a mechanism that links EMT to microRNAs (Place et al. 2008). Based on the above data, miR-373 is considered a putative tumor suppressor; however, miR-372 and miR-373 act as oncogenes in testicular germ cell tumors by debilitating the p53 pathway, thus allowing tumor growth in the presence of wild-type $\mathrm{p} 53$ (Voorhoeve et al. 2006).

Based on the fact that miR-126, miR-206, and miR-335 are down-regulated in metastatic breast cancer cells, these miRNAs are considered metastasis suppressors. Restoration of miR-126, miR-335, or miR-206 in highly metastatic MDA-MB-231-derivatives decreased their lung colonization capacity and bone metastasis (Tavazoie et al. 2008). In particular, miR-206 also inhibited primary tumor formation in mice implanted with MDA-MB-231 in their mammary fat pad. Notably, although the metastatic potential 
and motility were reduced, re-expression of these microRNAs did not alter the levels of the mesenchymal marker vimentin. Therefore, inhibition of metastasis was not due to a classical mesenchymal-to-epithelial transition (MET), despite the fact that cells changed their structure to a more rounded form (Tavazoie et al. 2008). Based on the observations outlined above, miR-126 exerts "dual" roles, since it mediates the action of VEGF, as described previously, but it plays a tumor suppressor role in breast cancer.

It is well established that proteases play significant roles in determining the invasive and metastatic potential of tumor cells. Recently, it was shown that KLK6 and KLK10 human tissue kallikrein-related peptidases are regulated by let-7f (Chow et al. 2008). Targeting of uPAR by miRNAs was also demonstrated (Hua et al. 2006). The uPAR is not only responsible for angiogenesis but also is involved in promoting metastasis of cancer cells. Furthermore, uPAR was found to induce EMT in breast cancer cells (Lester et al. 2007). Modulation of miR-21 expression was shown to correlate with the expression of MMP2 and MMP9 in human hepatocellular cancer (HCC); however, this is mediated by the PTEN tumor suppressor, which is a direct target of miR-21 (Meng et al. 2007).

\section{DEREGULATION MECHANISMS OF MICRORNA SWITCHES IN CANCER}

Deregulation of miRNA molecular switches during cancer development and metastasis is supported by an increasing number of studies. How this deregulation is initiated is currently unclear. However, it seems to involve the interplay of multiple mechanisms, such as genomic alterations, oncogenic transcription factors, epigenetic mechanisms, and hypoxia (O'Donnell et al. 2005; Kulshreshtha et al. 2007; Giannakakis et al. 2008). In some cases, protein or miRNA products of oncogenic viruses are responsible for the origin of deregulation (Pfeffer and Voinnet 2006). Genomic mutations in major "caretaker" genes, as for example the key regulator p53 tumor suppressor, deregulate multiple cellular mechanisms that can in turn deregulate the miRNA switches. Independent of the original causative effect, the endpoint is always the acquisition by the cancer cell of the six hallmark characteristics (Hanahan and Weinberg 2000). The major mechanisms underlying the deregulation of miRNA switches will be outlined in the following section, as they have emerged in numerous recent studies.

\section{Genomic alterations}

Genomic alterations often account for deregulated miRNA expression profiles in cancer. For example, down-regulation of miR-15 and miR-16 in CLL was described above. A detailed analysis of 283 different miRNA genes for gene copy number (gain or loss) in ovarian, breast, and melanoma cancer clinical specimens and/or cell lines was performed recently (Zhang et al. 2006b). Gene amplification was demonstrated for miR-17-92 (Hayashita et al. 2005). The mode of miR-223 regulation in leukemia represents an interesting example of how gross genomic alterations may be involved in the deregulation of miRNA switches. It was shown that the $\mathrm{t}(8 ; 21)$ translocation associated with primary leukemia produces the oncogenic factor AML1/ETO. By recruiting chromatin remodeling enzymes at an AML1binding site on the pre-miR-223 gene, AML1/ETO induces heterochromatic silencing of miR-223. Thereby, the miR-223 signaling pathway is turned off (Fazi et al. 2007). This example further illustrates the interconnection of multiple regulatory pathways and extends our understanding of the integrated circuit of the cancer cell in that gross genomic alterations lead to the production of a new tumor-specific oncogenic factor that induces epigenetic silencing of a miRNA by chromatin remodeling.

\section{Transcriptional regulation of microRNAs}

Changes in the expression levels of transcription factors known for their oncogenic or tumor suppressor function may have a direct effect on the expression of miRNAs. In gastric cancer, E2F1 overexpression is positively correlated with overexpression of the miR-106b-25 cluster (Petrocca et al. 2008). The oncogenic transcription factor c-MYC regulates the expression of the miR-17-92 cluster by binding to E-boxes located on the promoter of the miRNA gene (O'Donnell et al. 2005). Importantly, as discussed above, the miR-34 family is down-regulated in a panel of cancer cells due to p53 inactivation (Hermeking 2007). In addition, p53 was shown to directly bind to the miR-145 gene promoter to activate its transcription (Sachdeva et al. 2009). MiR-145 exerts an important tumor suppressor activity by silencing c-myc expression (Sachdeva et al. 2009).

\section{Epigenetic regulation of microRNAs}

Aberrant DNA methylation, which is a major cause of genome instability, can be triggered by miR-29 targeting of the DNA methyltransferases DNMT3a and DNMT3b. Specifically, it was shown that expression of the miR-29 cluster (29a, 29b, 29c) was down-regulated in lung cancer, while the de novo DNA methyltransferases DNMT3A and DNMT3B were up-regulated. Restoration of miR-29s expression resulted in normal patterns of DNA methylation in lung cancer cell lines, re-expression of epigenetically silenced tumor suppressor genes, such as WWOX and FHIT, and inhibition of tumorigenicity in vitro and in vivo (Fabbri et al. 2007). MiR-1 was identified by expression profiling of hepatocellular carcinoma cell lines treated with 5-aza-dC and/ or TSA. In DNMT1 ${ }^{-/-}$HCT116 the miR-1 gene was found hypomethylated and activated. Re-expression of miR-1 results in inhibition of cell growth and reduction 
of replication potential and clonogenic survival in HepG2 cells, indicating a putative tumor suppressor role in analogy with the classical tumor suppressor genes silenced by DNA hypermethylation (Datta et al. 2008). The tumor suppressor role of miR-1 was also demonstrated in lung cancer cell lines (Nasser et al. 2008). Other examples include miR-9-1, which was found hypermethylated in breast cancer cells (Lehmann et al. 2008) and miR-203, which is silenced either by DNA methylation or genomic deletion (Bueno et al. 2008). Identification of miRNAs that are regulated by DNA methylation was attempted by differential profiling of miRNA expression patterns in DNMT1 and DNMT3b double-gene knockouts in HCT116 cells (Han et al. 2007), and in metastatic lymph node cancer cells after 5 -aza-2'-dCinduced demethylation (Lujambio et al. 2008).

\section{Polymorphisms and mutations in microRNAs}

Point mutations or polymorphisms in miRNA genes may have implications in cancer, since they may abnormally turn on/off miRNAs that act as molecular switches in the integrated circuit of the cancer cell. Also, mutations in miRNA target sequences in mRNAs will have an impact on gene expression. For the human dihydrofolate reductase (DHFR) gene, it was found that a single nucleotide polymorphism (SNP) (C829T) at the 3' UTR occurs inside the miR-24 recognition sequence, resulting in DHFR overexpression associated with methotrexate resistance (Mishra et al. 2007). Cells with a mutant DHFR 3' UTR exhibited a twofold increase in mRNA half-life, expressed higher DHFR mRNA and protein, while they were four times more resistant to methotrexate. This SNP was named miRSNP (SNP located at or near the microRNA binding site) (Mishra et al. 2007). A similar polymorphism was also found in target mRNA encoding the angiotensin II type 1 receptor (AT1R) at the A1166C binding position recognized by miR155 (Martin et al. 2006; Sethupathy et al. 2007). Moreover, a SNP in the complementary site of let-7 in K-RAS increases the risk for nonsmall lung cancer (Chin et al. 2008). Recently, the PolymiRTS Database (http://compbio.utmem. edu/miRSNP) was constructed to collect naturally occurring DNA variations in putative microRNA target sites (Bao et al. 2007). In a large comprehensive study published by Iwai and Naraba (2005), 96 individuals were analyzed for 173 different miRNAs. Polymorphisms were identified in various regions of 10 different miRNAs. Only one polymorphic site in miR-30c-2 was localized in the recognition sequence, which is speculated to alter the selection of mRNA targets. Recently, another study was published showing sequence variations in one precursor miRNA and 15 pri-miRNAs in various human cancer cells lines (Diederich and Haber 2006). Finally, a large study for human polymorphisms in 227 miRNAs was performed that led to the identification of 323 polymorphisms (Duan et al. 2007). One of these polymorphisms was located in the eighth nucleotide of mature miR-125a, which is expected to block processing of pri-miRNA to pre-miRNA in addition to reducing miRNAmediated translational suppression.

\section{MICRORNAS ENCODED BY ONCOGENIC VIRUSES: EXTERNAL SWITCHES TO THE CELLULAR CIRCUIT}

Up to $15 \%$ of human cancers are associated with a single or multiple viral infections (Pfeffer and Voinnet 2006). The first evidence for the presence of miRNAs in oncogenic viruses came from the observation that the Epstein-Barr virus produces a large number of miRNAs (Pfeffer et al. 2004). The discovery of viral miRNAs indicates that miRNAs are critical modulators of virus-induced oncogenesis. Viral miRNAs can also act as molecular switches to turn on/off cellular microcircuits but may also be involved in the regulation of viral genes. EBV has been studied in detail and expresses a total of 23 miRNAs. These are arranged in two clusters. Twenty miRNAs are located in introns of the viral BART gene (miR-BART1-20), while three miRNAs are located adjacent to BHRF1 (miR-BHRF1-1-3) (Grundhoff et al. 2006). All 23 miRNAs were successfully mapped in EBV-infected cells by a combination of bioinformatic approaches for viral miRNA prediction and analysis of microarray data (Grundhoff et al. 2006). EBV is also associated with $\sim 6 \%-16 \%$ of gastric carcinoma cases. It was demonstrated that BART but not BHRF1 miRNAs are expressed in EBV-infected gastric carcinoma cell lines, in animal models, and in tumor samples from patients (Kim et al. 2007). Viral miRNAs were found that recognize and target viral transcripts, as demonstrated for EBV-encoded miR-BART2 that down-regulates the viral DNA polymerase BALF5, which represent a mechanism of virus self-regulation (Barth et al. 2008). Further, infection with EBV results in upregulation of miR-155 and its precursor RNA BIC. MiR-155 modulates the NF- $\mathrm{KB}$ pathway, thus contributing to EBVimmortalization ( $\mathrm{Lu}$ et al. 2008).

Kaposi's sarcoma-associated herpesvirus (KSHV) encodes for 12 different miRNAs that are detected during the latency period and are expressed from a single genetic locus (Cai et al. 2005). The KSHV miRNA (miR-K12-10) was shown to undergo RNA editing (Pfeffer et al. 2005). Since most viral miRNAs display no sequence conservation with metazoan miRNAs, they are not expected to interfere with endogenous miRNAs. Therefore, their ectopic expression allows for the identification of their targets and delineation of their functions. This approach was successfully applied to the identification of KSHV cellular targets. As mentioned, thrombospondin 1 (THBS1) represents a major target for KSHV miRNAs, since multiple KSHV miRNAs (miR-K12-1, miRK12-3-3p, miR-K12-6-3p, and miR-K12-11) target THBS1 expression (Samols et al. 2007). THBS1 was found to be down-regulated in Kaposi sarcoma lesions and has known activity as a strong tumor suppressor and antiangiogenic factor, exerting its antiangiogenic effect in part by activating 
latent TGF $\beta$ (Samols et al. 2007). MiR-K12-11, a miRNA encoded by KSHV, is an exception to the rule, since it displays significant homology with cellular miR-155, including the entire seed region. It was experimentally shown that expression of physiological levels of miR-K12-11 or miR-155 results in down-regulation of an extensive set of common mRNA targets, including genes with known roles in cell growth regulation, suggesting that viral miR-K12-11 functions as an ortholog of cellular miR-155 (Gottwein et al. 2007).

It is essential to understand the role(s) that these viral miRNAs may play in oncogenesis (for review, see Pfeffer and Voinnet 2006). Based on current knowledge, they can act directly as oncogenes, as demonstrated for the KSHV miRK12-10 and miR-K12-12. Interestingly, the p53 tumor suppressor is targeted by the EBV-encoded miR-BHRF1-1. Viral miRNAs can additionally facilitate tumor progression in tissues that are already prone to develop cancer in the absence of an infection. In a mouse B-cell lymphoma model it was found that enforced expression of the miR-17-92 cluster significantly accelerated lymphoma development $(\mathrm{He}$ et al. 2007). It is therefore possible that some viral miRNAs act similarly to the human oncomir miR-17-92. Finally, viral miRNAs facilitate evasion of innate and adaptive immune responses, thereby enabling long-lasting infections that are presumably required to establish a ground for cancer development. A recent computational study suggested the presence of one miRNA in hepatitis B virus (HBV) that was confirmed by Northern blot analysis. However, no cellular targets were predicted for this miRNA; therefore, it is possible that this miRNA acts as a virus self-regulatory mechanism (Jin et al. 2007). Among the many viruses that are known to infect the human liver, $\mathrm{HBV}$ and hepatitis $\mathrm{C}$ virus $(\mathrm{HCV})$ are unique because of their prodigious capacity to cause persistent infection, cirrhosis, and liver cancer (for review, see Guidotti and Chisari 2006). The physiological RNAi mechanism operating in mammalian cells is thought to contribute to antiviral defense. Contrary to this, knockdown of Dicer inhibits HCV replication. Further, human miR-122 contributes to $\mathrm{HCV}$ replication. Depletion of human miR-122 by modified antisense oligonucleotides prevents the production of infectious viral particles (Randall et al. 2007). This is the first example of how an oncogenic virus exploits the RNAi factory of the cell for its own replication. Finally, it is interesting to note that human papilloma virus HPV31 does not seem to encode for any miRNAs, and it is possible that this is a general feature of human papilloma viruses (Cai et al. 2006).

\section{EXPLOITATION OF MICRORNAS IN MOLECULAR DIAGNOSIS OF CANCER}

MicroRNAs have tremendous potential as a new class of molecular tumor biomarker, since the extraordinary level of diversity in their expression across human cancers can provide a large amount of diagnostic, prognostic, and predictive information. Because this information is encoded by a relatively small number of miRNAs when compared with the many thousands of transcripts analyzed for gene expression profiling, analysis of miRNAs is much more effective for succesful mining of novel tumor biomarkers suitable for routine clinical applications. Numerous recent studies have shown clearly that specific miRNAs display differential expression in tumors and their adjacent normal tissues and that specific miRNA expression signatures are correlated with prognosis, indicating that miRNAs are determinants of clinical aggressiveness (Calin et al. 2004; Lu et al. 2005; Volinia et al. 2006; Zhang et al. 2007a). MiRNA signatures were used to successfully classify human cancers and to define miRNA markers for favorable prognosis (Lu et al. 2005). As shown in Table 1, miR-10b, miR$125 \mathrm{~b}$, and miR-145 were found to be down-regulated in human breast cancer while miR-21 and miR-155 were upregulated (Iorio et al. 2005; Si et al. 2007). MicroRNA-21 (miR-21) has been shown to be up-regulated in breast cancer (Iorio et al. 2005), lung cancer (Volinia et al. 2006), and glioblastoma (Ciafrè et al. 2005). Interestingly, mature miR-21 has been associated with reduced overall survival of NSCLC patients (Markou et al. 2008). On the other side, miRNA-205 (miR-205) was shown to be overexpressed in head and neck cancer when compared with other cancer lines from lung, breast, colorectal, prostate, and pancreas (Jiang et al. 2005) and in bladder cancer (Gottardo et al. 2007). Yanaihara et al. (2006) have shown for the first time that miRNA expression profiles are diagnostic and prognostic markers in lung cancer. In lung cancer, reduced let-7 expression was found to be significantly associated with shortened postoperative survival, independent of disease stage (Takamizawa et al. 2004), while the expression of miRNA cluster mir-17-92 was found to have remarkably increased, especially in small cell lung cancer (Hayashita et al. 2005). A microRNA signature was found to be associated with prognosis and progression in chronic lymphocytic leukaemia (Calin et al. 2005). MicroRNA expression patterns were shown to differentiate pancreatic adenocarcinoma from normal pancreas and chronic pancreatitis, six miRNAs were proposed to be used as prognostic biomarkers, while 21 miRNAs were found to differentiate tumors from normal pancreatic tissues (Bloomston et al. 2007). Altogether, deregulated expression of miRNAs is a frequent occurrence in diverse types of cancer, highlighting the potential utility of miRNA profiling for molecular diagnosis and prognosis (Lu et al. 2005).

\section{THERAPEUTIC IMPLICATIONS: IS PHARMACOLOGICAL MODULATION OF MICRORNA SWITCHES FEASIBLE?}

As described, it is becoming increasingly evident that miRNA switches play important roles in regulating the cell circuit. Several miRNA switches are deregulated in cancer 
cells, thus contributing to the acquisition and progression of malignant phenotypes. Pharmacological modulation of miRNA expression may contribute to "normalization" of the malignant phenotypes, and, therefore, it could represent a potential approach in cancer therapeutics. This will require a better understanding of miRNA functions in the different steps of tumor formation and progression. A number of recent technological advances will be helpful in this direction, for example, RNA interference (RNAi), which is used to knock down the expression of genes of interest (for review, see Martin and Caplen 2007). The bestcharacterized triggers of RNAi are siRNAs. In addition, systems used for in vivo delivery of siRNAs could be also applied for the delivery of miRNAs. Interestingly, artificial miRNAs, or amiRNAs, were designed recently and used for gene targeting in plants (Niu et al. 2006). Such amiRNAs could be designed to target specific oncogenes. A synthetic miRNA that targets the chemokine receptor CXCR4 was designed using the backbone of miR-155 (Liang et al. 2007), based on a previous observation that siRNA targeting of the CXCR4 inhibited metastasis of breast cancer cells in vivo (Liang et al. 2004). This miRNA, when introduced into MDA-MB-231 breast cancer cells, reduced in vitro motility and invasion, as well as in vivo lung metastatic sites (Liang et al. 2007). In a similar study, the $P R L-3$ gene was targeted by a modified miR-155 (Li et al. 2006). The development of locked nucleic acids (LNAs) will aid the therapeutic applications of miRNAs. In these analogs, the ribose ring is locked by a methylene brigde connecting the $2^{\prime}$-O atom with the $4^{\prime}-\mathrm{C}$ atom (Petersen et al. 2002). LNAs were shown to exhibit no toxicity at dosages capable of producing antitumor effects in vivo. Specifically, inhibition of tumor growth in vivo by an LNA-based anti-H-RAS oligonucleotide was observed at $0.5 \mathrm{mg} \times \mathrm{kg}^{-1} \times \mathrm{d}^{-1}$ with no signs of toxicity (Fluiter et al. 2005). Increasing the dose above $1 \mathrm{mg} \times \mathrm{kg}^{-1} \times \mathrm{d}^{-1}$ resulted in inhibition of tumor growth that, however, was observed not only for LNAs targeting H-RAS, but also with mismatch control oligonucleotides. This indicates that miRNA-unrelated mechanism(s) may underlie the observed effect (Fluiter et al. 2005). LNAs were also used as probes for Northern blot analysis (Válóczi et al. 2004). Recently, targeting of miR-122 by LNA and peptide nucleic acids (PNAs) in human and rat liver cells was described (Fabani and Gait 2008). Efficient uptake of PNAs was achieved by conjugation of PNAs to a cell-permeable peptide (Fabani and Gait 2008). LNAs were also used to knock down the expression of miR-21 (Corsten et al. 2007). Further, LNAs were used to target miR-122 in African green monkeys and in mice, indicating that they have the potential to be used in humans (Elmén et al. 2008). Another chemical modification that has been introduced and used along with LNAs includes cholesterol-conjugated complementary miRNAs that were named antagomirs (Krützfeldt et al. 2005). In addition to chemically modified oligonucleotides, "miRNA sponges" were used recently as
microRNA inhibitors that are expressed intracellularly under the control of a strong promoter (Ebert et al. 2007). These are RNA molecules with multiple miRNA binding sites that are complementary to the heptameric seeding sequence; therefore, unlike chemically modified oligonucleotides that can target only one miRNA, a single miRNA sponge can block an entire miRNA seed family. Finally, the combination of miRNA targeting with classical chemotherapy or radiation therapy may provide new tools against cancer. As mentioned, re-expression of miR-221/222 in ER $\alpha$-negative breast cancer cells sensitizes cells to tamoxifen (Zhao et al. 2008). In lung cancer, the combination of let-7 reactivation (let-7a or let-7b) and radiation therapy improved efficacy (Weidhaas et al. 2007).

\section{CONCLUSIONS}

In the last two years, our knowledge of the roles of miRNAs in cancer has expanded significantly, as shown by the tremendous number of reported studies. Bioinformatic tools, e.g., search algorithms and databases, enabled the identification of a large number of novel miRNAs that will eventually allow for the construction of the miRNome of normal and cancer cells. This calls for a revision of the integrated cancer-cell circuit originally described by Hanahan and Weinberg (2000) to include not only the established signaling pathways but also the "miRNA switches" that set them on and off. In a systems biology approach, miRNAs should prospectively be included in the complete cell interactome along with protein-protein or protein-small molecule interaction networks, as recently attempted by the construction of the let-7a interactome (Sampson et al. 2007). These networks will extend our understanding of the roles of miRNAs in normal physiology and pathophysiology. Additionally, they can be exploited for informed choices in cancer chemotherapy in a way similar to pharmacogenomics. Nonetheless, important questions remain to be answered before miRNAs can be used therapeutically. For example, a high complexity of miRNA mechanisms of action was revealed by a recent study that showed dual roles of miRNAs. It was shown that miR-369-3, let-7, and the synthetic miRNA CXCR4 all could activate the translation of mRNAs during cell cycle arrest, but they inhibited translation during cell proliferation by recruiting the protein-activating complexes on AU-rich elements (AREs) of mRNAs at the $3^{\prime}$ end. Recruitment is mediated by binding of the miRNA to its complementary sequence on the target mRNA (Vasudevan et al. 2007). Complexity is further increased by additional mechanisms of mRNA activation that include miRNA binding sequences at gene promoter regions, as described for E-cadherin (Place et al. 2008). Finally, it remains to be answered whether we can use miRNA profiling for cancer prognosis and/or selection of chemotherapy. Mapping of all human miRNAs and the availability of complete miRNA microarrays will be required to address this question 
successfully. In addition, the development of animal models will extend our understanding of the physiological functions of miRNAs and will allow testing and validation of miRNA targeting for therapeutic purposes.

\section{ACKNOWLEDGMENTS}

We acknowledge financial support to G.S. through K. Karatheodoris Grant No. C.186, funded by the Research Committee of the University of Patras.

\section{REFERENCES}

Adams BD, Furneaux H, White B. 2007. The micro-RNA miR-206 targets the human estrogen receptor- $\alpha$, and represses ER $\alpha$ mRNA and protein expression in breast cancer cell lines. Mol Endocrinol 21: 1132-1147.

Akao Y, Nakagawa Y, Kitabe Y, Kinoshita T, Naoe T. 2007. Downregulation of miR-143 and miR-145 in B-cell malignancies. Cancer Sci 12: 1914-1920.

Altuvia Y, Landgraf P, Lithwick G, Elefant N, Pfeffer S, Aravin A, Brownstein MJ, Tuschl T, Margalit H. 2005. Clustering and conservation patterns of human microRNAs. Nucleic Acids Res 33: $2697-2706$

Alvarez-Garcia I, Miska EA. 2005. MicroRNA functions in animal development and human disease. Development 132: 4653-4662.

Asangani IA, Rasheed SA, Nikolova DA, Leupold JH, Colburn NH, Post S, Allgayer H. 2008. MicroRNA-21 (miR-21) post-transcriptionally down-regulates tumor suppressor Pdcd4 and stimulates invasion, intravasation, and metastasis in colorectal cancer. Oncogene 27: 2128-2136.

Bao L, Zhou M, Wu L, Lu L, Goldowitz D, Williams RW, Cui Y, Polymi RTS. 2007. Database: Linking polymorphisms in microRNA target sites with complex traits. Nucleic Acids Res 35: D51D54.

Bartel DP. 2004. MicroRNAs: Genomics, biogenesis, mechanism, and function. Cell 116: 281-297.

Barth S, Pfuhl T, Mamiani A, Ehses C, Roemer K, Kremmer E, Jäker C, Höck J, Meister G, Grässer FA. 2008. Epstein-Barr virusencoded microRNA miR-BART2 down-regulates the viral DNA polymerase BALF5. Nucleic Acids Res 36: 666-675.

Bass BL. 2002. RNA editing by adenosine deaminases that act on RNA. Annu Rev Biochem 71: 817-846.

Benetti R, Gonzalo S, Jaco I, Muñoz P, Gonzalez S, Schoeftner S, Murchison E, Andl T, Chen T, Klatt P, et al. 2008. A mammalian microRNA cluster controls DNA methylation and telomere recombination via Rbl2-dependent regulation of DNA methyltransferases. Nat Struct Mol Biol 15: 268-279.

Berezikov E, Chung WJ, Willis J, Cuppen E, Lai EC. 2007. Mammalian mirtron genes. Mol Cell 28: 328-336.

Bernstein E, Caudy AA, Hammond SM, Hannon GJ. 2001. Role for a bidentate ribonuclease in the initiation step of RNA interference. Nature 409: 363-366.

Blackburn EH. 2001. Switching and signalling at the telomere. Cell 1067: 661-673.

Bloomston M, Frankel WL, Petrocca F, Volinia S, Alder H, Hagan JP, Liu CG, Bhatt D, Taccioli C, Croce CM. 2007. MicroRNA expression patterns to differentiate pancreatic adenocarcinoma from normal pancreas and chronic pancreatitis. JAMA 297: 1901-1908.

Bommer GT, Gerin I, Feng Y, Kaczorowski AJ, Kuick R, Love RE, Zhai Y, Giordano TJ, Qin ZS, Moore BB, et al. 2007. p53-mediated activation of miRNA34 candidate tumor-suppressor genes. Curr Biol 17: 1298-1307.

Borchert GM, Lanier W, Davidson BL. 2006. RNA polymerase III transcribes human microRNAs. Nat Struct Mol Biol 13: 10971101.
Borgoño CA, Diamandis EP. 2004. The emerging roles of human tissue kallikreins in cancer. Nat Rev Cancer 4: 876-890.

Bottoni A, Piccin D, Tagliati F, Luchin A, Zatelli MC, degli Uberti EC. 2005. miR-15a and miR-16-1 down-regulation in pituitary adenomas. J Cell Physiol 204: 280-285.

Brueckner B, Stresemann C, Kuner R, Mund C, Musch T, Meister M, Sültmann H, Lyko F. 2007. The human let-7a-3 locus contains an epigenetically regulated microRNA gene with oncogenic function. Cancer Res 67: 1419-1423.

Bueno MJ, Pérez de Castro I, Gómez de Cedrón M, Santos J, Calin GA, Cigudosa JC, Croce CM, Fernández-Piqueras J, Malumbres M. 2008. Genetic and epigenetic silencing of microRNA-203 enhances ABL1 and BCR-ABL1 oncogene expression. Cancer Cell 13: 496-506.

Cai X, Lu S, Zhang Z, Gonzalez CM, Damania B, Cullen BR. 2005. Kaposi's sarcoma-associated herpesvirus expresses an array of viral microRNAs in latently infected cells. Proc Natl Acad Sci 102: 55705575.

Cai X, Li G, Laimins LA, Cullen BR. 2006. Human papillomavirus genotype 31 does not express detectable microRNA levels during latent or productive virus replication. J Virol 80: 10890-10893.

Calin GA, Croce CM. 2006. MicroRNA signatures in human cancers. Nat Rev Cancer 6: 857-866.

Calin GA, Dumitru CD, Shimizu M, Bichi R, Zupo S, Noch E, Aldler H, Rattan S, Keating M, Rai K, et al. 2002. Frequent deletions and down-regulation of microRNA genes miR15 and miR16 at 13q14 in chronic lymphocytic leukemia. Proc Natl Acad Sci 99: 15524-15529.

Calin GA, Sevignani C, Dumitru CD, Hyslop T, Noch E, Yendamuri S, Shimizu M, Rattan S, Bullrich F, Negrini M, et al. 2004. Human microRNA genes are frequently located at fragile sites and genomic regions involved in cancer. Proc Natl Acad Sci 101: 2999-3004.

Calin G, Ferracin M, Cimmino A, Di Leva G, Shimizu M, Wojcik SE, Iorio MV, Visone R, Sever NI, Fabbri M, et al. 2005. A microRNA signature associated with prognosis and progression in chronic lymphocytic leukemia. $N$ Engl J Med 353: 1793-1801.

Chang TC, Wentzel EA, Kent AO, Ramachandran K, Mullendore M, Lee KH, Feldmann G, Yamakuchi M, Ferlito M, Lowenstein CJ, et al. 2007. Transactivation of miR-43a by p53 broadly influences gene expression and promotes apoptosis. Mol Cell 26: 745-752.

Chen Y, Gorski DH. 2008. Regulation of angiogenesis through a microRNA (miR-130a) that down-regulates antiangiogenic homeobox genes GAX and HOXA5. Blood 111: 1217-1226.

Chendrimada TP, Gregory RI, Kumaraswamy E, Norman J, Cooch N, Nishikura K, Shiekhattar R. 2005. TRBP recruits the Dicer complex to Ago2 for microRNA processing and gene silencing. Nature 436: 740-744.

Chin LJ, Ratner E, Leng S, Zhai R, Nallur S, Babar I, Muller RU, Straka E, Su L, Burki EA, et al. 2008. A SNP in a let-7 microRNA complementary site in the KRAS $3^{\prime}$ untranslated region increases nonsmall cell lung cancer risk. Cancer Res 68: 8535-8540.

Chiosea S, Jelezcova E, Chandran U, Acquafondata M, McHale T, Sobol RW, Dhir R. 2006. Up-regulation of Dicer, a component of the microRNA machinery, in prostate adenocarcinomas. Am J Pathol 169: 1812-1820.

Chiosea S, Jelezcova E, Chandran U, Luo J, Mantha G, Sobol RW, Dacic S. 2007. Overexpression of Dicer in precursor lesions of lung adenocarcinoma. Cancer Res 67: 2345-2350.

Cho WC. 2007. OncomiRs: The discovery and progress of microRNAs in cancers. Mol Cancer 6: 60.

Chow TF, Chow M, Earle T, El-Said H, Diamandis EP, Yousef GM. 2008. Kallikreins as microRNA targets: An in silico and experimentalbased analysis. Biol Chem 389: 731-738.

Christoffersen NR, Silahtaroglu A, Orom UA, Kauppineen S, Lund AH. 2007. miR-200b mediates post-transcriptional repression of ZFHX1B. RNA 13: 1172-1178.

Ciafrè SA, Galardi S, Mangiola A, Ferracin M, Liu CG, Sabatino G, Negrini M, Maira G, Croce CM, Farace MG. 2005. Extensive 
modulation of a set of microRNAs in primary gliobastoma. Biochem Biophys Res Commun 334: 1351-1358.

Cimmino A, Calin GA, Fabbri M, Iorio MV, Ferracin M, Shimizu M, Wojcik SE, Aqeilan RI, Zupo S, Dono M, et al. 2005. miR-15 and miR-16 induce apoptosis by targeting BCL2. Proc Natl Acad Sci 102: 13944-13949.

Corney DC, Flesken-Nikitin A, Godwin AK, Wang W, Nikitin AY. 2007. MicroRNA-34b and microRNA-34c are targets of p53 and cooperate in control of cell proliferation and adhesion-independent growth. Cancer Res 67: 8433-8438.

Corsten MF, Miranda R, Kasmieh R, Krichevsky AM, Weissleder R, Shah K. 2007. MicroRNA-21 knockdown disrupts glioma growth in vivo and displays synergistic cytotoxicity with neural precursor cell delived S-TRAIL in human gliomas. Cancer Res 67: 8994-9000.

Cui JW, Li YJ, Sarkar A, Brown J, Tan YH, Premyslova M, Michaud C, Iscove N, Wang GJ, Ben-David Y. 2007. Retroviral insertional activation of the Fli-3 locus in erythroleukemias encoding a cluster of microRNAs that convert Epo-induced differentiation to proliferation. Blood 100: 2631-2640.

Cummins JM, He Y, Leary RJ, Pagliarini R, Diaz LA Jr, Sjoblom T, Barad O, Bentwich Z, Szafranska AE, Labourier E, et al. 2006. The colorectal microRNAone. Proc Natl Acad Sci 103: 3687-3692.

Datta J, Kutay H, Nasser MW, Nuovo GJ, Wang B, Majumder S, Liu C-G, Volinia S, Croce CM, Schmittgen TD, et al. 2008. Methylation mediated silencing of microRNA-1 gene and its role in hepatocellular carcinogenesis. Cancer Res 68: 5049-5058.

Dews M, Homayouni A, Yu D, Murphy D, Sevignani C, Wentzel E, Furth EE, Lee WN, Enders GH, Mendell JT, et al. 2006. Augmentation of tumor angiogenesis by a Myc-activated microRNA cluster. Nat Genet 38: 1060-1065.

Diederich S, Haber DA. 2006. Sequence variations of microRNAs in human cancer: Alterations in predicted secondary structure do not affect processing. Cancer Res 66: 6097-6104.

$\mathrm{Du}$ T, Zamore PD. 2005. MicroPrimer: The biogenesis and function of microRNA. Development 132: 4645-4652.

Duan R, Pak C, Jin P. 2007. Single nucleotide polymorphism associated with mature miR-125a alters the processing of pri-miRNA. Hum Mol Genet 16: 1124-1131.

Ebert MS, Neilson JR, Sharp PA. 2007. MicroRNA sponges: Competitive inhibitors of small RNAs in mammalian cells. Nat Methods 4: 721-726.

Eis PS, Tam W, Sun L, Chadburn A, Li Z, Gomez MF, Lund E, Dahlberg JE. 2005. Accumulation of miR-155 and BIC RNA in human B cell lumphomas. Proc Natl Acad Sci 102: 3627-3632.

Elmén J, Lindow M, Schütz S, Lawrence M, Petri A, Obad S, Lindholm M, Hedtjärn M, Hansen HF, Berger U, et al. 2008. LNA-mediated microRNA silencing in nonhuman primates. Nature 452: 896-899.

Esquela-Kerscher A, Slack FJ. 2006. Oncomirs-MicroRNAs with a role in cancer. Nat Rev Cancer 6: 259-269.

Fabani MM, Gait MJ. 2008. miR-122 targeting with LNA/2'-O-methyl oligonucleotide mixmers, peptide nucleic acids (PNA), and PNA peptide conjugates. RNA 14: 336-346.

Fabbri M, Garzon R, Cimmino A, Liu Z, Zanesi N, Callegari E, Liu S, Alder H, Costinean S, Fernandez-Cymering C, et al. 2007. MicroRNA29 family reverts aberrant methylation in lung cancer by targeting DNA methyltransferases 3A and 3B. Proc Natl Acad Sci 104: 1580515810.

Fazi F, Racanicchi S, Zardo G, Starnes LM, Mancini M, Travaglini L, Diverio D, Ammatuna E, Cimino G, Lo-Coco F, et al. 2007. Epigenetic silencing of the myelopoiesis regulator microRNA-223 by the AML1/ETO oncoprotein. Cancer Cell 12: 457-466.

Fedi P, Tronick SR, Aaronson SA. 1997. Growth factors. In Cancer medicine (eds. JF Holland et al.), pp. 41-64. Williams and Wilkins, Baltimore, MD.

Filipowicz W, Bhattacharyya SN, Sonenberg N. 2008. Mechanisms of post-transcriptional regulation by microRNAs: Are the answers in sight? Nat Rev Genet 9: 102-114.
Fish JE, Santoro MM, Morton SU, Yu S, Yeh RF, Wythe JD, Ivey KN, Bruneau BG, Stainier DY, Srivastava D. 2008. miR-126 regulates angiogenic signaling and vascular integrity. Dev Cell 15: 272-284.

Fluiter K, Frieden M, Vreijling J, Rosebohm C, De Wissel MB, Christensen SM, Koch T, Ørum H, Baas F. 2005. On the in vitro and in vivo properties of four locked nucleic acid nucleotides incorporated into an anti-H-Ras antisense oligonucleotides. ChemBioChem 6: 1104-1109.

Frankel LB, Christoffersen NR, Jacobsen A, Lindow M, Krogh A, Lund AH. 2008. Programmed cell death 4 (PDCD4) is an important functional target of the microRNA miR-21 in breast cancer cells. $J$ Biol Chem 283: 1026-1033.

Forman JJ, Legesse-Miller A, Coller HA. 2008. A search for conserved sequences in coding regions reveals that the let-7 microRNA targets dicer within its coding sequence. Proc Natl Acad Sci 39: 14879-14884.

Giannakakis A, Sandaltzopoulos R, Greshock J, Liang S, Huang J, Hasegawa K, Li C, O’Brien-Jenkins A, Katsaros D, Weber BL, et al. 2008. miR-210 links hypoxia with cell cycle regulation and is deleted in human epithelial ovarian cancer. Cancer Biol Ther 7: 255-264.

Gottardo F, Liu CG, Ferranic M, Calin GA, Fassan M, Bassi P, Sevignani C, Byrne D, Negrini M, Pagano F, et al. 2007. MicroRNA profiling in kidney and bladder cancers. Urol Oncol 25: 387-392.

Gottwein E, Mukherjee N, Sachse C, Frenzel C, Majoros WH, Chi JT, Braich R, Manoharan M, Soutschek J, Ohler U, et al. 2007. A viral microRNA functions as an orthologue of cellular miR-155. Nature 450: 1096-1099.

Gregory RI, Chendrimada TP, Cooch N, Shiekhattar R. 2004. The Microprocessor complex mediates the genesis of microRNAs. Nature 432: 235-240.

Gregory RI, Chendrimada TP, Cooch N, Shiekhattar R. 2005. Human RISC couples microRNA biogenesis and post-transcriptional gene silencing. Cell 123: 631-640.

Grishok A, Pasquinelli AE, Conte D, Li N, Parrish S, Ha I, Baillie DL, Fire A, Ruvkun G, Mello CC. 2001. Genes and mechanisms related to RNA interference regulate expression of the small temporal RNAs that control C. elegans developmental timing. Cell 106: 23-34.

Grundhoff A, Sullivan CS, Ganem D. 2006. A combined computational and microarray-based approach identifies novel microRNAs encoded by human $\gamma$-herpesviruses. RNA 12: 733-750.

Guidotti LG, Chisari FV. 2006. Immunobiology and pathogenesis of viral hepatitis. Annu Rev Pathol 1: 23-61.

Han L, Witmer PD, Casey E, Valle D, Sukumar S. 2007. DNA methylation regulates microRNA expression. Cancer Biol Ther 6: 1284-1288.

Hanahan D, Weinberg RA. 2000. The hallmarks of cancer. Cell 100: 57-70.

Hannon GJ, Beach D. 1994. p15INK4B is a potential effector of TGF$\beta$-induced cell cycle arrest. Nature 371: 257-261.

Hayashita Y, Osada H, Tatematsu Y, Yamada H, Yanagisawa K, Tomida S, Yatabe Y, Kawahara K, Sekido Y, Takahashi T. 2005. A polycistronic microRNA cluster, miR-17-92, is overexpressed in human lung cancers and enhances cell proliferation. Cancer Res 65: 9628-9632.

He H, Jazdzewski K, Li W, Liyanarachchi S, Nagy R, Volinia S, Calin GA, Liu CG, Franssila K, Suster S, et al. 2005a. The role of microRNA genes in papillary thyroid carcinoma. Proc Natl Acad Sci 102: 19075-19080.

He L, Thomson JM, Hemann MT, Hernando-Monge E, Mu D, Goodson S, Powers S, Cordon-Cardo C, Lowe SW, Hannon GJ, et al. 2005b. A microRNA polycistron as a potential human oncogene. Nature 435: 828-833.

He L, He X, Lim LP, de Stanchina E, Xuan Z, Liang Y, Xue W, Zender L, Magnus J, Ridzon D, et al. 2007. A microRNA component of the p53 tumour suppressor network. Nature 447: $1130-1134$.

Hermeking H. 2007. p53 enters the microRNA world. Cancer Cell 12: 411-418. 
Horikawa T, Yang J, Kondo S, Yoshizaki T, Joab I, Furukawa M, Pagano JS. 2007. Twist and epithelial-mesenchymal transition are induced by the EBV oncoprotein latent membrane protein 1 and are associated with metastatic nasopharyngeal carcinoma. Cancer Res 67: 1970-1978.

Hossain A, Kuo MT, Saunders GF. 2006. Mir-17-5p regulates breast cancer cell proliferation by inhibiting translation of AIB1 mRNA. Mol Cell Biol 26: 8191-8201.

Hua Z, Lv Q, Ye W, Wong CKA, Cai G, Gu D, Ji Y, Zhao C, Wang J, Yang BB, et al. 2006. miRNA-directed regulation of VEGF and other angiogenic factors under hypoxia. PLoS One 1: e116. doi: 10.1371/journal.pone.0000116.

Huang Q, Gumireddy K, Schrier M, le Sage C, Nagel R, Nair S, Egan DA, Li A, Huang G, Klein-Szanto AJ, et al. 2008. The microRNAs miR-373 and miR-520c promote tumour invasion and metastasis. Nat Cell Biol 10: 202-210.

Hutvágner G, Simard MJ. 2008. Argonaute proteins: Key players in RNA silencing. Nat Rev Mol Cell Biol 9: 22-32.

Hutvágner G, McLachlan J, Pasquinelli AE, Bálint E, Tuschl T, Zamore PD. 2001. A cellular function for the RNA-interference enzyme Dicer in the maturation of the let-7 small temporal RNA. Science 293: 834-838.

Hwang H-W, Wentzel EA, Mendell JT. 2007. A hexanucleotide element directs miRNA nuclear import. Science 315: 97-100.

Ibarra I, Erlich Y, Muthuswamy SK, Sachidanandam R, Hanon GJ. 2007. A role for microRNAs in maintenance of mouse mammary epithelial progenitor cells. Genes \& Dev 21: 3238-3243.

Iorio MV, Ferracin M, Liu CG, Veronese A, Spizzo R, Sabbioni S, Magri E, Pedriali M, Fabbri M, Campiglio M, et al. 2005. MicroRNA gene expression deregulation in human breast cancer. Cancer Res 65: 7065-7070.

Iorio MV, Visone R, Di Leva G, Donati V, Petrocca F, Casalinin P, Taccioli C, Volinia S, Liu CG, Alder H, et al. 2007. MicroRNA signatures in human ovarian cancer. Cancer Res 67: 8699-8707.

Irvin-Wilson CV, Chaudhuri G. 2005. Alternative initiation and splicing in dicer gene expression in human breast cells. Breast Cancer Res 7: R563-R569.

Iwai N, Naraba H. 2005. Polymorphisms in human pre-miRNAs. Biochem Biophys Res Commun 331: 1439-1444.

Jiang J, Lee EJ, Gusev Y, Schmittgen TD. 2005. Real-time expression profiling of microRNA precursors in human cancer cell lines. Nucleic Acids Res 33: 5394-5403.

Jin P, Alisch RS, Warren ST. 2004. RNA and microRNAs in fragile X mental retardation. Nat Cell Biol 6: 1048-1053.

Jin WB, Wu FL, Kong D, Guo AG. 2007. HBV-encoded microRNA candidate and its target. Comput Biol Chem 31: 124-126.

Johnson SM, Grosshans H, Shingara J, Byrom M, Jarvis R, Cheng A, Labourier E, Reinert KL, Brown D, Slack FJ. 2005. RAS is regulated by the let-7 microRNA family. Cell 120: 635-647.

Karube Y, Tanaka H, Osada H, Tomida S, Tatematsu Y, Yanagisawa K, Yatabe Y, Takamizawa J, Miyoshi S, Mitsudomi T, et al. 2005. Reduced expression of Dicer associated with poor prognosis in lung cancer patients. Cancer Sci 96: 111-115.

Kawahara Y, Zinshteyn B, Chendrimada TP, Shiekhattar R, Nishikura K. 2007a. RNA editing of the microRNA-151 precursor blocks cleavage by the Dicer-TRBP complex. EMBO Rep 8: 763 769.

Kawahara Y, Zinshteyn B, Sethupathy P, Iizasa H, Hatzigeorgiou AG, Nishikura K. 2007b. Redirection of silencing targets by adenosineto-inosine editing of miRNAs. Science 315: 1137-1140.

Ketting RF, Fischer SE, Bernstein E, Sijen T, Hannon GJ, Plasterk RH. 2001. Dicer functions in RNA interference and in synthesis of small RNA involved in developmental timing in C. elegans. Genes \& Dev 15: 2654-2659.

Kim DN, Chae HS, Oh ST, Kang JH, Park CH, Park WS, Takada K, Lee JM, Lee WK, Lee SK, 2007. Expression of viral microRNAs in Epstein-Barr virus-associated gastric carcinoma. J Virol 81: 10331036.
Kim VN, Han J, Siomi MC. 2009. Biogenesis of small RNAs in animals. Nat Rev Mol Cell Biol 10: 126-139.

Kiriakidou M, Tan GS, Lamprinaki S, De Planell-Saguer M, Nelson PT, Mourelatos Z. 2007. An mRNA m7G cap binding-like motif within human Ago2 represses translation. Cell 129: 11411151.

Korpal M, Lee ES, Hu G, Kang Y. 2008. The miR-200 family inhibits epithelial-mesenchymal transition and cancer cell migration by direct targeting of E-cadherin transcriptional repressors ZEB1 and ZEB2. J Biol Chem 283: 14910-14914.

Krützfeldt J, Rajewsky N, Braich R, Rajeev KG, Tuschl T, Manoharan M, Stoffel M. 2005. Silencing of microRNAs in vivo with 'antagomirs.' Nature 438: 685-689.

Kuehbacher A, Urbich C, Zeiher AM, Dimmeler S. 2007. Role of Dicer and Drosha for endothelial microRNA expression and angiogenesis. Circ Res 101: 59-68.

Kulshreshtha R, Ferracin M, Wojcik SE, Garzon R, Alder H, AgostoPerez FJ, Danuluri R, Liu CG, Croce CM, Negrini M, et al. 2007. A microRNA signature of hypoxia. Mol Cell Biol 27: 1859-1867.

Kumar MS, Lu J, Mercer KL, Golub TR, Jacks T. 2007. Impaired microRNA processing enhances cellular transformation and tumorigenesis. Nat Genet 39: 673-677.

Kutay H, Bai S, Datta J, Motiwala T, Pogribny I, Frankel W, Jacob ST, Ghoshal K. 2006. Down-regulation of miR-122 in the rodent and human hepatocellular carcinomas. J Cell Biochem 99: 671-678.

Lee YS, Dutta A. 2007. The tumor suppressor microRNA let-7 represses the HMGA2 oncogene. Genes \& Dev 21: 1025-1030.

Lee RC, Feinbaum RL, Ambros V. 1993. The C. elegans heterochronic gene lin-4 encodes small RNAs with antisense complementarity to lin-14. Cell 5: 843-854.

Lee YS, Kim M, Han J, Yeom KH, Lee S, Baek SH, Kim VN. 2004. MicroRNA genes are transcribed by RNA polymerase II. EMBO J 23: 4051-4060.

Lee DY, Deng Z, Wang CH, Yang BB. 2007a. MicroRNA-378 promotes cell survival, tumor growth, and angiogenesis by targeting $\mathrm{SuFu}$ and Fus-1 expression. Proc Natl Acad Sci 104: 20350-20355.

Lee JW, Choi CH, Choi JJ, Park YA, Kim SJ, Hwang SY, Kim WY, Kim TJ, Lee JH, Kim BG, et al. 2007b. Altered microRNA expression in cervical carcinomas. Clin Cancer Res 14: 25352542.

Lee JW, Choi CH, Choi JJ, Park YA, Kim SJ, Hwang SY, Kim WY, Kim TJ, Lee JH, Kim BG, et al. 2008. Altered microRNA expression in cervical carcinomas. Clin Cancer Res 14: 2535-2542.

Lehmann U, Hasemeier B, Christgen M, Müller M, Römermann D, Länger F, Kreipe H. 2008. Epigenetic inactivation of microRNA gene hsa-mir-9-1 in human breast cancer. J Pathol 214: 17-24.

Lester RD, Jo M, Montel V, Takimoto S, Gonias SL. 2007. uPAR induces epithelial-mesenchymal transition in hypoxic breast cancer cells. J Cell Biol 178: 425-436.

Li Z, Zhan W, Wang Z, Zhu B, He Y, Peng J, Cai S, Ma J. 2006. Inhibition of PRL-3 gene expression in gastric cancer cell line SGC7901 via microRNA suppressed reduces peritoneal metastasis. Biochem Biophys Res Commun 348: 229-237.

Liang Z, Wu T, Lou H, Yu X, Taichman RS, Lau SK, Nie S, Umbreit J, Shim H. 2004. Inhibition of breast cancer metastasis by selective synthetic polypeptide against CXCR4. Cancer Res 64: 4302-4308.

Liang Z, Wu H, Reddy S, Zhu A, Wang S, Blevins D, Yoon Y, Zhang Y, Shim H. 2007. Blockade of invasion and metastasis of breast cancer cells via targeting CXCR4 with an artificial miRNA. Biochem Biophys Res Commun 363: 542-546.

Liu J, Carmell MA, Rivas FV, Marsden CG, Thomson JM, Song JJ, Hammond SM, Joshua-Tor L, Hannon GJ. 2004. Argonaute2 is the catalytic engine of mammalian RNAi. Science 305: 1437-1441.

Liu X, Fortin K, Mourelatos Z. 2008. MicroRNAs: Biogenesis and molecular functions. Brain Pathol 18: 113-121.

Lo AL, To KF, Lung RW, Hui JW, Liao G, Hayward SD. 2007. Modulation of LMP1 protein expression by EBV-encoded microRNAs. Proc Natl Acad Sci 104: 16164-16169. 
Löffler D, Brocke-Heidrich K, Pfeifer G, Stocsits C, Hackermüller J, Kretzschmar AK, Burger R, Gramatzki M, Blumert C, Bauer K, et al. 2007. Interleukin-6 dependent survival of multiple myeloma cells involves the Stat3-mediated induction of microRNA-21 through a highly conserved enhancer. Blood 110: 1330-1333.

Lu J, Getz G, Miska EA, Alvarez-Saavedra E, Lamb J, Peck D, et al. 2005. MicroRNA expression profiles classify human cancers. Nature 435: 834-848.

Lu Y, Thomson JM, Wong HY, Hammond SM, Hogan BL. 2007. Transgenic over-expression of the microRNA miR-17-92 cluster promotes proliferation and inhibits differentiation of lung epithelial progenitor cells. Dev Biol 310: 442-453.

Lu F, Weidmer A, Liu CG, Volinia S, Croce CM, Lieberman PM. 2008. Epstein-Barr virus-induced miR-155 attenuates NF- $\mathrm{\kappa B}$ signaling and stabilizes latent virus persistance. J Virol 82: 10436-10443.

Luciano DJ, Mirsky H, Vendetti NJ, Maas S. 2004. RNA editing of a miRNA precursor. RNA 10: 1174-1177.

Lui WO, Pourmand N, Patterson BK, Fire A. 2007. Patterns of known and novel small RNAs in human cervical cancer. Cancer Res 67: 6031-6043.

Lujambio A, Ropero S, Ballestar E, Fraga MF, Cerrato C, Setien F, Casado S, Suarez-Gauthier A, Sanchez-Cespedes M, Git A, et al. 2007. Genetic unmasking of an epigenetically silenced microRNA in human cancer cells. Cancer Res 67: 1424-1429.

Lujambio A, Calin GA, Villanueva A, Ropero S, Sánchez-Céspedes M, Blanco D, Montuenga LM, Rossi S, Nicoloso MS, Faller WJ, et al. 2008. A microRNA DNA methylation signature for human cancer metastasis. Proc Natl Acad Sci 105: 13556-13561.

Lund E, Güttinger S, Calado A, Dahlberg JE, Kutay U. 2004. Nuclear export of microRNA precursors. Science 303: 95-98.

Ma L, Teruya-Feldstein J, Weiberg RA. 2007. Tumour invasion and metastasis initiated by microRNA-10b in breast cancer. Nature 449: 682-688.

Markou A, Tsaroucha EG, Kaklamanis L, Fotinou M, Georgoulias V, Lianidou E. 2008. Prognostic value of mature microRNA-21 and microRNA-205 overexpression in nonsmall cell lung cancer by quantitative real-time RT-PCR. Clin Chem 4: 1696-1704.

Martin SE, Caplen NJ. 2007. Applications of RNA interference in mammalian systems. Annu Rev Genomics Hum Genet 8: 81-90.

Martin MM, Buckenberger JA, Jiang J, Malana GE, Nuovo GJ, Chotani M, Feldman DS, Schmittgen TD, Elton TS. 2006. The human angiotensin II type 1 receptor $+1166 \mathrm{~A} / \mathrm{C}$ polymorphism attenuates microrna-155 binding. J Biol Chem 282: 24262-24269.

Mathonnet G, Fabian MR, Svitkin YV, Parsyan A, Huck L, Murata T, Biffo S, Merrick WC, Darzynkiewicz E, Pillai RS, et al. 2007. MicroRNA inhibition of translation initiation in vitro by targeting the cap-binding complex eIF4F. Science 317: 1764-1767.

Meister G, Landthaler M, Patkaniowska A, Dorsett Y, Teng G, Tuschl T. 2004. Human Argonaute2 mediates RNA cleavage targeted by miRNAs and siRNAs. Mol Cell 15: 185-197.

Mejlvang J, Kriajevska M, Vandewalle C, Chernova T, Savan AE, Berx G, Mellon JK, Tulchinsky E. 2007. Direct repression of cyclin D1 by SIP1 attenuates cell cycle progression in cells undergoing an epithelial mesenchymal transition. Mol Biol Cell 18: 46154624.

Meng F, Henson R, Lang M, Wehbe H, Maheshwari S, Mendell JT, Jiang J, Schmittgen TD, Patel T. 2006. Involvement of human micro-RNA in growth and response to chemotherapy in human cholangiocarcinoma cell lines. Gastroenterology 130: 2113-2129.

Meng F, Henson R, Wehbe-Janek H, Ghoshal K, Jacob ST, Patel T. 2007. MicroRNA-21 regulates expression of the PTEN tumor suppressor gene in human hepatocellular cancer. Gastroenterology 133: $647-658$.

Michael MZ, O'Connor SM, van Holst Pellekaan NG, Young GP, James RJ. 2003. Reduced accumulation of specific microRNAs in colorectal neoplasia. Mol Cancer Res 1: 882-891.

Miller TE, Ghoshal K, Ramaswamy B, Roy S, Datta J, Shapiro CL, Jacob S, Majumber S. 2008. MicroRNA-221/222 confers tamoxifen resistance in breast cancer by targeting p27(Kip1). J Biol Chem 283: 29897-29903.

Mishra PJ, Humeniuk R, Mishra PJ, Long-Sorbello GS, Banerjee D, Bertino JR. 2007. A miR-24 microRNA binding-site polymorphism in dihydrofolate reductase gene leads to methotrexate resistance. Proc Natl Acad Sci 14: 13513-13518.

Mitomo S, Maesawa C, Ogasawara S, Iwaya T, Shibazaki M, YashimaAbo A, Kotani K, Oikawa H, Sakurai E, Izutsu N, et al. 2008. Down-regulation of miR-138 is associated with overexpression of human telomerase reverse transcriptase protein in human anaplastic thyroid carcinoma cell lines. Cancer Sci 99: 280-286.

Muntoni A, Redder RR. 2005. The first molecular details of ALT in human tumor cells. Hum Mol Genet 14: R191-R196.

Nasser MW, Datta J, Nuovo G, Kutay H, Motiwala T, Majumber S, Wang B, Suster S, Jacob ST, Ghoshal K. 2008. Down-regulation of microRNA-1 (miR-1) in lung cancer: Suppression of tumorigenic property of lung cancer cells and their sensitization to doxorubicin induced apoptosis by miR-1. J Biol Chem 283: 3339433405.

Negrini M, Rasio D, Hampton GM, Sabbioni S, Rattan S, Carter SL, Rosenberg AL, Schwartz GF, Shiloh Y, Cavenee WK, et al. 1995. Definition and refinement of chromosome 11 regions of loss of heterozygosity in breast cancer: Identification of a new region at 11q23.3. Cancer Res 55: 3003-3007.

Nelson PT, Baldwin DA, Scearce LM, Oberholtzer JC, Tobias JW, Mourelatos Z. 2004. Microarray-based, high-throughput gene expression profiling of microRNAs. Nat Methods 1: 155-161.

Niu QW, Lin SS, Reyes JL, Chen KC, Wu HW, Yeh SD, Chua NH. 2006. Expression of artificial microRNAs in transgenic Arabidopsis thaliana confers virus resistance. Nat Biotechnol 24: 1420-1428.

Niu RF, Zhang L, Xi GM, Wei XY, Yang Y, Shi YR, Hao XS. 2007. Upregulation of Twist induces angiogenesis and correlates with metastasis in hepatocellular carcinoma. J Exp Clin Cancer Res 26: 385-394.

O’Donnell KA, Wentzel EA, Zeller KI, Dang CV, Mendrell JT. 2005. c-Myc-regulated microRNAs modulate E2F1 expression. Nature 435: 839-843.

Okamura K, Hagen JW, Duan H, Tyler DM, Lai EC. 2007. The mirtron pathway generates microRNA-class regulatory RNAs in Drosophila. Cell 130: 89-100.

Ovcharenko D, Kelnar K, Johnson C, Leng N, Brown D. 2007. Genome-scale microRNA and small interfering RNA screens identify small RNA modulators of TRAIL-induced apoptosis pathway. Cancer Res 67: 10782-10788.

Pallante P, Visone R, Ferracin M, Ferraro A, Berlingieri MT, Troncone G, Chiappetta G, Liu CG, Santoro M, Negrini M, et al. 2006. MicroRNA deregulation in human thyroid papillary carcinomas. Endocr Relat Cancer 13: 497-508.

Peters L, Meister G. 2007. Argonaute proteins: Mediators of RNA silencing. Mol Cell 26: 611-623.

Petersen M, Bondensgaard K, Wengel J, Jacobsen JP. 2002. Locked nucleic acid (LNA) recognition of RNA: NMR solution structures of LNA:RNA hybrids. J Am Chem Soc 124: 5974-5982.

Petrocca F, Visone R, Onelli MR, Shah MH, Nicoloso MS, de Martino I, Iliopoulos D, Pilozzi E, Liu CG, Negrini M, et al. 2008. E2F1-regulated microRNAs impair TGF $\beta$-dependent cellcycle arrest and apoptosis in gastric cancer. Cancer Cell 13: 272-286.

Pfeffer S, Voinnet O. 2006. Viruses, microRNAs, and cancer. Oncogene 25: 6211-6219.

Pfeffer S, Zavolan M, Grasser FA, Chien M, Russo JJ, Ju J, John B, Enright AJ, Marks D, Sander C, et al. 2004. Identification of virusencoded microRNAs. Science 304: 734-736.

Pfeffer S, Sewer A, Lagos-Quintana M, Sheridan R, Sander C, Grässer FA, van Dyk LF, Ho CK, Shuman S, Chien M, et al. 2005. Identification of microRNAs of the herpesvirus family. Nat Methods 2: 269-276.

Pillai RS, Bhattacharyya SN, Artus CG, Zoller T, Cougot N, Basyuk E, Bertrand E, Filipowicz W. 2005. Inhibition of translational 
initiation by let-7 microRNA in human cells. Science 309: 15731576.

Place RF, Li LC, Pookot D, Noonan EJ, Dahiya R. 2008. MicroRNA373 induces expression of genes with complementary promoter sequences. Proc Natl Acad Sci 105: 1608-1613.

Poliseno L, Tuccoli A, Mariani L, Evangelista M, Citti L, Woods K, Mercatanti A, Hammond S, Rainaldi G. 2006. MicroRNAs modulate the angiogenic properties of HUVECs. Blood 108: 30683071.

Porkka KP, Pfeiffer MJ, Waltering KK, Vessella RL, Tammela TLJ, Visakorpi T. 2007. MicroRNA expression profiling in prostate cancer. Cancer Res 67: 6130-6135.

Rand TA, Ginalski K, Grishin NV, Wang X. 2004. Biochemical identification of Argonaute 2 as the sole protein required for RNA-induced silencing complex activity. Proc Natl Acad Sci 101: 14385-14398.

Randall G, Panis M, Cooper JD, Tellinghuisen TL, Sukhodolets KE, Pfeffer S, Landthaler M, Landgraf P, Kan S, Lindenbach D, et al. 2007. Cellular cofactors affecting hepatitis $C$ virus infection and replication. Proc Natl Acad Sci 104: 12884-12889.

Rasio D, Negrini M, Manenti G, Dragani TA, Croce CM. 1995. Loss of heterozygosity at chromosome $11 \mathrm{q}$ in lung adenocarcinoma: Identification of three independent regions. Cancer Res 55: 39883991.

Raver-Shapira N, Marciano E, Meiri E, Spector Y, Rosenfeld N, Moskovits N, Bentwich Z, Oren M. 2007. Transcriptional activation of miR-34a contributes to p53-mediated apoptosis. Mol Cell 26: $731-743$.

Reya T, Morrisson SJ, Clarke MF, Weissman IL. 2001. Stem cells, cancer, and cancer stem cells. Nature 414: 105-111.

Rivas FV, Tolia NH, Song JJ, Aragon JP, Liu J, Hannon GJ, JoshuaTor L. 2005. Purified Argonaute2 and an siRNA form recombinant human RISC. Nat Struct Mol Biol 12: 340-349.

Roldo C, Missiaglia E, Hagan JP, Falconi M, Capelli P, Bersani S, Calin GA, Volinia S, Liu CG, Scarpa A, et al. 2006. MicroRNA expression abnormalities in pancreatic endocrine and acinar tumors are associated with distinctive pathologic features and clinical behavior. J Clin Oncol 24: 4677-4684.

Ruby JG, Jan CH, Bartel DP. 2007. Intronic microRNA precursors that bypass Drosha processing. Nature 448: 83-86.

Sachdeva M, Zhu S, Wu F, Wu H, Walia V, Kumar S, Elble R, Watabe K, Mo YY. 2009. p53 represses c-myc through induction of the tumor suppressor miR-145. Proc Natl Acad Sci 106: 3207-3212.

Samols MA, Skalsky RL, Maldonado AM, Riva A, Lopez MC, Baker HV, Renne R. 2007. Identification of cellular genes targeted by KSHV-encoded microRNAs. PLoS Pathog 3: e65. doi: 10.1371/ journal.ppat.0030065.

Sampson VB, Rong NH, Han J, Yang Q, Aris V, Soteropoulos P, Petrelli NJ, Dunn SP, Krueger LJ. 2007. MicroRNA let-7a downregulates MYC and reverts MYC-induced growth in Burkitt lymphoma cells. Cancer Res 67: 9762-9770.

Scott GK, Goga A, Bhaumik D, Berger CE, Sullivan CS, Benz CC. 2007. Coordinate suppression of ERBB2 and ERBB3 by enforced expression of microRNA miR-125a or miR-125b. J Biol Chem 282: 1479-1486.

Shell S, Park SM, Radjabi AR, Schickel R, Kistner EO, Jewell DA, Feig C, Lengyel E, Peter ME. 2007. let-7 expression defines two differentiation stages of cancer. Proc Natl Acad Sci 104: 1140011405.

Sheng Y, Engström PG, Lenhard B. 2007. Mammalian microRNA prediction through a support vector machine model of sequence and structure. PLoS One 2: e946. doi: 10.1371/journal.pone. 0000946.

Sethupathy P, Borel C, Gagnebin M, Grant GR, Deutsch S, Elton TS, Hatzigeorgiou AS, Antonarakis SE. 2007. Human microRNA-155 on chromosome 21 differentially interacts with its polymorphic target in the AGTR1 $3^{\prime}$ untranslated region: A mechanism for functional single-nucleotide polymorphisms related to phenotypes. Am J Hum Genet 81: 405-413.
Shi XB, Xue L, Yang J, Ma AH, Zhao J, Xu M, Tepper CG, Evans CP, Kung HJ, deVere White RW. 2007. An androgen-regulated miRNA suppresses Bak1 expression and induces androgen-independent growth of prostate cancer cells. Proc Natl Acad Sci 104: 1998319988.

Si ML, Zhu S, Wu H, Lu Z, Wu F, Mo YY. 2007. miR-21 mediated tumor growth. Oncogene 26: 2799-2803.

Sinkkonen L, Hugenschmidt T, Berninger P, Gaidatzis D, Mohn F, Artus-Revel CG, Zavolan M, Svoboda P, Filipowicz W. 2008. MicroRNA control de novo DNA methylation through regulation of transcriptional repressors in mouse embryonic stem cells. Nat Struct Mol Biol 15: 259-267.

Song JJ, Smith SK, Hannon GJ, Joshua-Tor L. 2004. Crystal structure of argonaute and its implications for RISC slicer activity. Science 305: 1434-1437.

Sonkoly E, Wei T, Janson PC, Sääf A, Lundeberg L, TengvallLinder M, Norstedt G, Alenius H, Homey B, Scheynius A, et al. 2007. MicroRNAs: Novel regulators involved in the pathogenesis of psoriasis? PLoS One 2: e670. doi: 10.1371/journal.pone. 0000610 .

Takamizawa J, Konishi H, Yanagisawa K, Tomida S, Osada H, Endoh H, et al. 2004. Reduced expression of the let-7 microRNAs in human lung cancers in association with shortened postoperative survival. Cancer Res 64: 3753-3756.

Takanabe R, Ono K, Abe Y, Takaya T, Horie T, Wada H, Kita T, Satoh N, Shimatsu A, Hasegawa K. 2008. Up-regulated expression of microRNA-143 in association with obesity in adipose tissue of mice fed high-fat diet. Biochem Biophys Res Commun 376: 728732.

Talotta F, Cimmino A, Matarazzo MR, Casalino L, De Vita G, D’Esposito M, Di Lauro R, Verde P. 2009. An autoregulatory loop mediated by miR-21 and PDCD4 controls the AP-1 activity in RAS transformation. Oncogene 28: 73-84.

Tang X, Tang G, Ozcan S. 2008. Role of microRNAs in diabetes. Biochim Biophys Acta 1779: 697-701.

Tarasov V, Jung P, Verdoodt B, Lodygin D, Epanchintsev A, Menssen A, Meister G, Hermeking H. 2007. Differential regulation of microRNAs by p53 revealed by massively parallel sequencing: miR-34a is a p53 target that induces apoptosis and G1-arrest. Cell Cycle 6: 1586-1593.

Tavazoie SF, Alarcón C, Oskarsson T, Padua D, Wang Q, Bos PD, William GL, Massagué J. 2008. Endogenous human microRNAs that suppress breast cancer metastasis. Nature 451: 147-152.

Tazawa H, Tsuchiya N, Izumiya M, Nakagama H. 2007. Tumorsuppressor miR-34a induces senescence-like growth arrest through modulation of the E2F pathway in human colon cancer cells. Proc Natl Acad Sci 104: 15472-15477.

Thiery JP. 2002. Epithelial-mesenchymal transitions in tumour progression. Nat Rev Cancer 2: 442-454.

Thuault S, Valcourt U, Petersen M, Manfioletti G, Heldin CH, Moustakas A. 2006. Transforming growth factor- $\beta$ employs HMGA2 to elicit epithelial-mesenchymal transition. J Cell Biol 174: $175-183$.

Tsonis PA, Call MK, Grogg MW, Sartor MA, Taylor RR, Forge A, Fyffe R, Goldenberg R, Cowper-Sal-lari R, Tomlinson CR. 2007. MicroRNAs and regeneration: Let-7 members in lens and inner ear hair cell regeneration of the adult newt. Biochem Biophys Res Commun 362: 940-945.

Válóczi A, Hornyik C, Varga N, Burgyán J, Kauppinen S, Havelda Z. 2004. Sensitive and specific detection of microRNAs by northern blot analysis using LNA-modified oligonucleotide probes. Nucleic Acids Res 32: e175. doi: 10.1093/nar/gnh171.

Vasudevan S, Tong Y, Steitz JA. 2007. Switching form repression to activation: MicroRNAs can up-regulate translation. Science 318: 1931-1934.

Volinia S, Calin GA, Liu CG, Ambs S, Cimmino A, Petrocca F, Visone R, Iorio M, Roldo C, Ferracin M, et al. 2006. A microRNA expression signature of human solid tumors defines cancer gene targets. Proc Natl Acad Sci 103: 2257-2261. 
Voorhoeve PM, le Sage C, Schrier M, Gillis AJ, Stoop H, Nagel R, Liu YP, van Duijse J, Drost J, Griekspoor A, et al. 2006. A genetic screen implicates miRNA-372 and miRNA-373 as oncogenes in testicular germ cell tumors. Cell 124: 1169-1181.

Wang CL, Wang BB, Bartha G, Li L, Channa N, Klinger M, Killeen N, Wabl M. 2006. Activation of an oncogenic microRNA cistron by provirus integration. Proc Natl Acad Sci 103: 18680-18684.

Wang S, Aurora AB, Johnson BA, Qi X, McAnally J, Hill JA, Richardson JA, Bassel-Duby R, Olson EN. 2008a. The endothelial-specific microRNA miR-126 governs vascular integrity and angiogenesis. Dev Cell 15: 261-271.

Wang WX, Rajeev BW, Stromberg AJ, Ren N, Tang G, Huang Q, Rigoutsos I, Nelson PT. 2008b. The expression of microRNA miR107 decreases early in Alzheimer's disease and may accelerate disease progression through regulation of $\beta$-site amyloid precursor protein-cleaving enzyme 1. J Neurosci 28: 1213-1223.

Watnick RS, Cheng YN, Rangarajan A, Ince TA, Weinberg RA. 2003. Ras modulates Myc activity to repress thrombospondin-1 expression and increase tumor angiogenesis. Cancer Cell 3: 219231.

Weidhaas JB, Badar I, Nallur SM, Trang P, Roush S, Boehm M, Gillespie E, Slack EJ. 2007. MicroRNAs as potential agents to alter resistance to cytotoxic anticancer therapy. Cancer Res 67: 1111111116.

Welch C, Chen Y, Stalling RL. 2007. MicroRNA-34a functions as a potential tumor suppressor by inducing apoptosis in neuroblastoma cells. Oncogene 26: 5017-5022.

Wong TS, Liu XB, Wong BY, Ng RW, Yuen AP, Wei WI. 2008. Mature miR-184 as potential oncogenic microRNA of squamous cell carcinoma of tongue. Clin Cancer Res 14: 2588-2592.

Xu C, Lu Y, Pan Z, Chu W, Luo X, Lin H, Xiao J, Shan H, Wang Z, Yang B. 2007. The muscle-specific microRNAs miR-1 and miR-133 produce opposing effects on apoptosis by targeting HSP60, HSP70 and caspase-9 in cardiomyocytes. J Cell Sci 120: 3045-3052.

Yanaihara N, Caplen N, Bowman E, Seike M, Kumamoto K, Yi M, Stephens RM, Okamoto A, Yokota J, Tanaka T, et al. 2006. Unique microRNA molecular profiles in lung cancer diagnosis and prognosis. Cancer Cell 9: 189-198.
Yang J, Mani SA, Donaher JL, Ramaswamy S, Itzykson RA, Come C, Savagner P, Gitelman I, Richardson A, Weinberg RA. 2004. Twist, a master regulator of morphogenesis, plays an essential role in tumor metastasis. Cell 104: 927-939.

Yang WJ, Yang DD, Na S, Sandusky GE, Zhang Q, Zhao G. 2005. Dicer is required for embryonic angiogenesis during mouse development. J Biol Chem 280: 9330-9335.

Yi R, Qin Y, Macara IG, Cullen BR. 2003. Exportin-5 mediates the nuclear export of pre-microRNAs and short hairpin RNAs. Genes \& Dev 17: 3011-3016.

Yu F, Yao H, Zhu P, Zhang X, Pan Q, Gong C, Huang Y, Hu X, Su F, Lieberman J, et al. 2007. let-7 regulates self-renewal and tumorigenicity of breast cancer cells. Cell 131: 1109-1123.

Zamore PD, Haley B. 2005. Ribo-gnome: The big world of small RNAs. Science 309: 1519-1524.

Zanette DL, Rivadavia F, Molfetta GA, Barbuzano FG, ProtSiqueira R, Falcão RP, Zago MA, Silva WA Jr. 2007. miRNA expression profiles in chronic lymphocytic and acute lymphocytic leukemia. Braz J Med Biol Res 40: 1435-1440.

Zhang B, Pan X, Anderson TA. 2006a. MicroRNA: A new player in stem cells. J Cell Physiol 209: 266-269.

Zhang L, Huang J, Yang N, Greshock J, Megraw MS, Giannakakis A, Liang S, Naylor TL, Barchetti A, Ward MR, et al. 2006b. MicroRNAs exhibit high frequency genomic alterations in human cancer. Proc Natl Acad Sci 103: 9136-9141.

Zhang B, Pan X, Cobb GP, Anderson TA. 2007a. MicroRNAs as oncogenes and tumor suppressors. Dev Biol 302: 1-12.

Zhang HH, Wang XJ, Li GX, Yang F, Yang NM. 2007b. Detection of let-7a microRNA by real-time PCR in gastric carcinoma. World $J$ Gastroenterol 13: 2883-2888.

Zhao JJ, Lin J, Yang H, Kong W, He L, Ma X, Coppola D, Cheng JQ. 2008. MicroRNA-221/222 negatively regulates ER $\alpha$ and associates with tamoxifen resistance in breast cancer. J Biol Chem 283: 31079-31086.

Zhu S, Si ML, Wu H, Mo YY. 2007. MicroRNA-21 targets the tumor suppressor gene tropomyosin 1 (TPM1). J Biol Chem 282: 1432814336.

Zhu S, Wu H, Wu F, Nie D, Sheng S, Mo YY. 2008. MicroRNA-21 targets tumor suppressor genes in invasion and metastasis. Cell Res 18: $350-359$. 

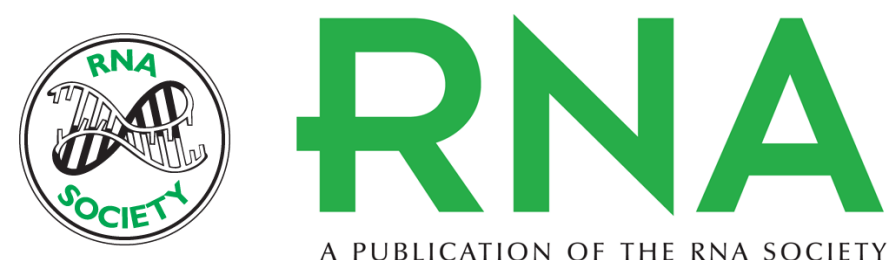

A PUBLICATION OF THE RNA SOCIETY

\section{Emerging roles of microRNAs as molecular switches in the integrated circuit of the cancer cell}

Georgia Sotiropoulou, Georgios Pampalakis, Evi Lianidou, et al.

RNA 2009 15: 1443-1461 originally published online June 26, 2009

Access the most recent version at doi:10.1261/rna.1534709

References This article cites 215 articles, 91 of which can be accessed free at:

http://rnajournal.cshlp.org/content/15/8/1443.full.html\#ref-list-1

License

Email Alerting Receive free email alerts when new articles cite this article - sign up in the box at the Service top right corner of the article or click here. 